Illinois State University

ISU ReD: Research and eData

Theses and Dissertations

6-3-2015

\title{
A Case Study of University Archives: Illinois State University Archives as a Model Archive
}

Tammy M. Hansen

Illinois State University, hansetam28@gmail.com

Follow this and additional works at: https://ir.library.illinoisstate.edu/etd

Part of the Library and Information Science Commons

\section{Recommended Citation}

Hansen, Tammy M., "A Case Study of University Archives: Illinois State University Archives as a Model Archive" (2015). Theses and Dissertations. 431.

https://ir.library.illinoisstate.edu/etd/431

This Thesis is brought to you for free and open access by ISU ReD: Research and eData. It has been accepted for inclusion in Theses and Dissertations by an authorized administrator of ISU ReD: Research and eData. For more information, please contact ISUReD@ilstu.edu. 


\title{
A CASE STUDY OF UNIVERSITY ARCHIVES: ILLINOIS STATE UNIVERSITY ARCHIVES
}

\section{AS A MODEL ARCHIVE}

\author{
Tammy M. Hansen
}

102 Pages

August 2015

Given the diversity of sizes, administrators, and archival theory, it would appear logical to think that college and university archives would vary greatly in their development, processes, collecting policies, and challenges. While there is some variation, there are more similarities in college and university archives than there are differences. This study of four state universities in Illinois examines theses similarities and differences, comparing them with the Illinois State University Archives and with best practices and standards set by the Society of American Archivists and the National Archives and Records Administration. 
A CASE STUDY OF UNIVERSITY ARCHIVES:

\section{ILLINOIS STATE UNIVERSITY ARCHIVES}

AS A MODEL ARCHIVE

TAMMY M. HANSEN

A Thesis Submitted in Partial Fulfillment of the Requirements for the Degree of

MASTER OF SCIENCE

Department of History

ILLINOIS STATE UNIVERSITY 
(C) 2015 Tammy M. Hansen 


\title{
A CASE STUDY OF UNIVERSITY ARCHIVES: \\ ILLINOIS STATE UNIVERSITY ARCHIVES
}

AS A MODEL ARCHIVE

\author{
TAMMY M. HANSEN
}

COMMITTEE MEMBERS:

Alan Lessoff, Chair

Patrice Olsen

April Karlene Anderson 


\section{ACKNOWLEDGMENTS}

There are so many people who have encouraged me, challenged me, and sacrificed their time and my attention for me to finally attain this goal. I would like to first thank my mom and dad, Jeanette and Jerry Thuotte, for always believing in me and supporting me. My children, Douglas, Zachary, Sarah, Hannah, and Lance have had to sacrifice time with and attention from me, and without their understanding, I would not have been able to complete my assignments without huge amounts of parental guilt.

To my coworkers in the Dean's Office of the College of Arts and Sciences - Dean Greg Simpson, Carrie Wieburg, Val Ilyuhkina, Deborah Fox, Sally Parry, Joe Blaney and Dagmar Persaud; and my former coworkers in Student Conduct and Conflict Resolution - Suzette Walden Cole, Janice Blair, and Akilah Jones; I would not have been able to accomplish what I have without your support and allowing me the time off I needed for classes, research, and writing.

A big shout out to my partners in crime, Deb Shaw and Dana Davidson, for our girls' nights out and fun times in Chicago. They were and are much needed time away from the toils of graduate school. Your support and encouragement has meant a great deal to me.

Of course, without Garth Piercy, I do not know if I could have made it through the past five years without your help. Thank you for all the coffee, breakfasts, lunches, and dinners. Thank you for taking care of Atticus when I have been late at the library, at 
class, writing, researching, or whatever I have had to do to get this done. Thank you for the laundry and grocery shopping I did not have to do, and the errands I did not have to run. Thank you for the encouragement, support and understanding.

And finally, thank you to my committee. My chair, Dr. Alan Lessoff, never let me by with mediocrity. His patience and direction are much appreciated and sorely needed. The advice he gave me about pursuing a thesis option only if I was passionate about my topic was the best advice I was given in the last three years. I am also grateful to the other committee members, Dr. Patrice Olsen who has been one of my best cheerleaders throughout my time at Illinois State, and ISU Archivist April Karlene Anderson who has taken so much of her valuable time to assist me in my research and has always been willing to answer my questions and encourage me in this endeavor.

T. M. H. 


\section{CONTENTS}

Page

ACKNOWLEDGMENTS

CONTENTS

CHAPTER

I. INTRODUCTION 1

II. HISTORY OF ILLINOIS STATE UNIVERSITY ARCHIVES 9

III. HISTORIES OF THREE STATE OF ILLINOIS UNIVERSITIES

IV. RECORDS LOST: THE NEED FOR AN ACTIVE RECORDS MANAGEMENT PROGRAM 53

V. COMPARISON OF THE UNIVERSITIES 70

$\begin{array}{lll}\text { VI. CONCLUSION } & 94\end{array}$

$\begin{array}{ll}\text { REFERENCES } & 98\end{array}$ 


\section{CHAPTER I}

\section{INTRODUCTION}

Professor Anderson is chairing her university's centennial celebration committee. The committee has decided that it would like to put together a slide show featuring photographs of past presidents. Where could the committee get these photographs? President Smith is considering a capital project to build a new dormitory. He heard that a former president had had a similar idea, but it was rejected. President Smith wants to know the details of that project and why it was rejected. Where could he get that information?

For many colleges and universities, the answer to the above questions would be the university's archives. There, non-current records of administrative and historical value are preserved for future use. These records consist of more than photographs and administrative reports. Archival theorist T. R. Schellenberg defined records as

All books, papers, maps, photographs, or other documentary materials, regardless of physical form or characteristics, made or received by any public or private institution in pursuance of its legal obligations or in connection with the transaction of its proper business and preserved or appropriate for preservation by that institution or its legitimate successor as evidence of its functions, policies, decisions, procedures, operations, or other activities or because of the informational value of the data contained therein. ${ }^{1}$

Oddly enough, university archives are relative newcomers in the realm of archives, with

\footnotetext{
${ }^{1}$ T. R. Schellenberg, Modern Archives: Principles and Techniques, (Chicago: The Society of American Archivists, 1956), 16.
} 
Harvard University officially establishing the first university archives in 1939. Other colleges and universities soon followed, establishing their own archives. Given the diversity of sizes, administrators, and archival theory, it would appear logical to think that college and university archives would vary greatly in their development, processes, collecting policies, and challenges. Yet, I have found that, using the Illinois State University (ISU) Archives as a model, while there is some variation, there are more similarities in college and university archives than there are differences. This became apparent during my examination and comparison of the archives at Southern Illinois University at Carbondale (SIUC), Eastern Illinois University (EIU), the University of Illinois (U of I), and the ISU archives.

At each archive, I researched their development, space, processes, collection policy, records management policy, and previous archivists through available records and interviews with the archivists. The findings for each archive will be laid out separately, followed by a discussion of the findings and how they compared with each other, and with archival theory and best practices.

Two factors that played a large role in academic archives developing along the same line were the training and education of American archivists. There was not an adequate manual in English that provided standardized archival procedures until T. R. Schellenberg's 1956 Modern Archives: Principles and Techniques, nor was there a 33 college and university archives would come from these early days of the profession.

Schellenberg believed an archivist should first have "a broad general training in some field of learning, and secondly, a specialized training in archival principles and 
techniques." In his opinion, the best training an archivist could have was training in history, because this provided "a knowledge of the development of his country and its government... [and] training in research methodology. ${ }^{2}$ In addition to having advanced training, preferably in history, Shellenberg held that an archivist's training should then be supplemented by archival training. ${ }^{3}$

Solon J. Buck, the National Archives' second archivist and president of the Society of American Archivists, referred to the body of knowledge an archivist should have as "archival science." This applied science, was, in his view, "compounded of parts of many other sciences or fields of knowledge, together with certain principles and techniques derived from practical experience." ${ }^{5}$ Buck advocated for a solid background in history and government, as well a more specialized knowledge in administrative history or government history and in the field to which the documents in his custody relate. To these, Buck added archival theory and archival history.

Buck also decried the lack of archival study programs in the United States. While he acknowledged there was a large body of literature on the subject, he lamented that "this literature is hard to find...[and] most of it [was] not available in English" ${ }^{6}$ He noted that the staff of the National Archives had to be recruited without any specialized knowledge in archival science due to the failure of institutions to provide archival education. Buck taught what he believed to be the first course designed specifically for archival training at Columbia University in 1938, which was not continued due to

\footnotetext{
${ }^{1}$ Ibid., 130.

${ }^{2}$ Ibid., 131.

${ }^{3}$ Ibid., 131.

${ }^{4}$ Solon J. Buck, "Training of American Archivists," The American Archivist 4, no. 2 (April 1941): 85.

${ }^{5}$ Ibid., 85.

${ }^{6}$ Ibid., 87.
} 
financial reasons. ${ }^{7}$ American University in Washington, D.C. began offering courses in archival studies in the early 1940s. In 1955, American University began offering a certificate in archival administration, with instructors such as Schellenberg and Oliver W. Holmes. ${ }^{8}$ By 1954, other programs existed in North Carolina, Wisconsin, and Colorado and continued to expand to other universities. ${ }^{9}$

Archivist H. G. Jones, however, believed that despite the expansion of educational opportunities for archivists, as a profession, archivists had "failed in [their] responsibility to [their] profession...to provide adequate, regular, and comprehensive training."10 He disagreed with the adequacy of Schellenberg's recommendation that archival studies be taught in library schools, as he did not believe that a librarian could adequately teach the subject without having "active archival experience."11 Instead, Jones proposed a program to draw graduate history students into the archival profession. This program would include an "in-depth study of recordmaking and recordkeeping,...an intensive study of archival procedures and techniques,... [and] a supervised period of inservice training in the repository."12 However, since many archival positions, both academic and non-academic, require an American Library Association-accredited master's degree in library science or library and information science, it would appear that Schellenberg's view prevailed.

Finally, in 2002, the Society of American Archivists endorsed a set of best practices for archival study. These included not only course work, but also practical

\footnotetext{
${ }^{7}$ Ibid., 88.

${ }^{8}$ H. G. Jones, “Archival Training in American Universities, 1938-68," The American Archivist 31, no. 2 (April 1968): 141.

${ }^{9}$ Robert M. Warner, "Archival Training in the United States and Canada," The American Archivist 35, no. 3-4 (July 1972): 349.

${ }^{10}$ Jones, 148.

${ }^{11}$ Ibid., 150.

${ }^{12}$ Ibid., 152-153.
} 
experience. For an institution to meet the standards, archival students had to have "regular and frequent access to archives and manuscript repositories. Repository access [could] take the form of class visits, research assignments in the repositories, and opportunities for internships and other types of practical experience."13

With the emphasis on practical experience in archives from the 1950s on, access to adequately staffed and administered archives could be a challenge to some universities. How was this challenge to be overcome? One way was for the university to have an archives for its own records. However, the focus for American Historical Association and the Society of American Archivists had been on state and federal governmental repositories, not on repositories for colleges and universities. While institutions of higher learning may have had archives for their research collections, most of them, seeing no value in the preservation of their records, had no official repositories for their records. If records were retained, many times they would be relegated to a storage closet or the bowels of a building. It was not until the early 1950s that colleges and universities began to realize the need for the adequate preservation and retention of their own records.

That is not to say that there was no interest in the preservation of university records prior to the 1950s. In the mid-1800s, Jared Sparks gathered together whatever Harvard College papers he could find and deposited them in the college's library. ${ }^{14}$ In the later 1800s, other presidents, professors, and librarians in New England colleges such as Dartmouth, Columbia University, and Amherst, also made an effort to collect and preserve their colleges' respective records. However, these attempts and others that

\footnotetext{
13 "Guidelines for a Graduate Program in Archival Studies," Society of American Archivists, accessed March 2, 2015, http://www2.archivists.org/gpas.

${ }^{14}$ John Melville Jennings, "Archival Activity in American Universities and Colleges," The American Archivist 12, no. 2 (April 1949): 155.
} 
followed were "prompted almost certainly by historical rather than administrative motives," usually because of an upcoming centennial or bicentennial celebration. ${ }^{15}$

Even where attempts were made to collect and preserve records, the records usually came under the control of a librarian rather than an archivist. Applying the library techniques to archival material usually resulted in the dissolution of the records' provenance, or the history of ownership, with materials being removed and scattered around the holdings. No thought was given to more recent noncurrent records, which "continued to languish in whatever quarters the creating offices cared or were able to provide."16

As colleges and universities grew, the output of records grew as well. Administrators began to realize that their record storage and arrangement systems, as well as their ability to have control over noncurrent records, were inadequate, to say the least. Finding that, for example, the university was bound by agreements that disappeared with the files of temporary heads of departments, led Harvard Corporation, the governing board of the university at that time, to enact measures in 1939 to ensure the success of their archival program and the preservation of records of both administrative and historical significance. ${ }^{17}$ Both governing boards of Montana State University and Fisk University also issued similar directives to ensure the preservation of records in 1945 and 1948, respectively. ${ }^{18}$

To follow up on this trend, the Society of American Archivists conducted a survey in the summer of 1949 to "determine the extent of archival awareness" in colleges

\footnotetext{
${ }^{15}$ Ibid., 155-156.

${ }^{16}$ Ibid., 156.

${ }^{17}$ Clifford K. Shipton, “The Harvard University Archives: Goal and Functions," Harvard Library Bulletin 1, no. 1 (Winter 1947): 101-102, accessed March 5, 2015, http://pds.lib.harvard.edu/pds/view/2573358.

18 Jennings, 159.
} 
and universities in the United States and Canada. ${ }^{19}$ What the committee found was disheartening. Of the 150 surveys sent, 115 responses were received. Of those 115,56 colleges and universities had archives, 15 preserved their records but had "no unified archival program," 11 kept some records, seven were "studying the problem with a view to establishing archives," 14 had records scattered throughout the university and were “interested in establishing archives," and 12 were "totally uninterested in archives.",20

Yet, there was a bright side to these data. Colleges and universities were beginning to understand that a one- or two-room archives was not sufficient for housing their administrative records, and they were beginning to employ full-time archivists. Those that did not have archives were beginning to plan for them properly rather than situating them in a dank basement or in a room in the library.

The committee conducted another survey in 1962. This survey was sent to the original 1949 colleges and universities plus 200 others, with a response from 268 institutions. Again, the results were disheartening. Of those institutions, $113 \mathrm{had}$ archival programs headed by a full- or part-time archivist. However, the archivist was likely to be a librarian who had been assigned to the role. The survey also found that though institutions may have an archives, many respondents indicated that "a room in the library or some other campus building had been set aside for valuable records, even though no archivist had been appointed to supervise them or to decide what records merited permanent preservation."21

\footnotetext{
${ }^{19}$ Dwight H. Wilson, "Archives in Colleges and Universities: Some Comments on Data Collected by the Society's Committee on College and University Archives," The American Archivist 13, no. 4 (October 1950): 343.

${ }^{20}$ Committee on College and University Archives, "Report of the Committee on College and University Archives," The American Archivist 13, no. 1 (January 1950): 63.

${ }^{21}$ Philip P. Mason, "College and University Archives: 1962," The American Archivist 26, no. 2 (April 1963): 162-163.
} 
In 1966, the committee conducted a comprehensive survey to "ascertain, first, if an institutional archives existed, and second, something about the nature and scope of the operation." ${ }^{22}$ Surveys were sent to 1,156 institutions in the United States and 46 in Canada. They received responses from 836 institutions in the United States and 45 in Canada. In the U.S., 278 institutions had no formal archives. On the bright side, 558 roughly 48 percent - of institutions had an archival program. However, only 53 institutions in both countries - 9 percent - employed professional archivists. Unchanged was the fact that most archives surveyed were part of the library and had a librarian as archivist.

${ }^{22}$ Robert M. Warner, "The Status of College and University Archives," The American Archivist 31, no. 3 (July 1968): 235. 


\section{CHAPTER II}

\section{HISTORY OF ILLINOIS STATE UNIVERSITY ARCHIVES}

Illinois State University, the first of twelve public universities in Illinois, was founded in 1857 as an institute of teacher education, with then-attorney Abraham Lincoln drawing up the bond guaranteeing that the residents would meet their financial obligations. It is located in the Town of Normal, which sits at the crossroads of three major interstate highways, and along the St. Louis-to-Chicago railway. By 2015, ISU had a student body of 20,762 on its 490 acre campus, with 71 undergraduate degree programs, 42 graduate degree programs, and 10 doctoral degree programs. As of the last financial audit in 2014, ISU showed revenues of \$560 million and expenses of $\$ 550$ million, leaving a positive balance of $\$ 10$ million. ISU's rich history and financial stability have made it a model institution for creating and maintaining its own archives. But that road has been bumpy, to say the least.

Like so many archives before and since, the ISU Archives was established because of the realization of the necessity to preserve the institution's records. Prior to its official founding by the decree of ISU President Samuel E. Braden on March 31, 1970, official records were scattered around the university in various offices, storage closets, and basements. Historical artifacts, such as the Civil War sword of the first college's president Charles E. Hovey and letters from Hovey before he was university president, 
were housed in a museum in Milner Library or again, scattered across the university or in the homes of former professors and alumni.

Braden designated the University Library as the "collector of archival material regarding Illinois State University," Collections department. The archive's mission was "to support the informational and research needs of the University and the wider community by preserving records pertaining to the origin and development of the University, including the achievements of its officers, employees, and students, and making those records available for use."2

Robert Sokan, whose specialty was rare books, was hired in 1969 as the special collections librarian. Since archives fell under Special Collections, Sokan was named the first archivist of Illinois State University. Sokan seemed less interested in the archives than in the rare book collection ISU was amassing. ${ }^{3}$

A memo from Joe W. Kraus, university librarian, to the deans, department heads and chairmen of university committees dated April 6, 1970 communicated the new position and how it would impact the aforementioned. The memo stated that the library would serve as the university archives to "preserve non-current papers that are likely to be useful in interpreting the history of the University." ${ }^{4}$ Kraus instructed university employees to contact Sokan prior to discarding any substantial files. ${ }^{5}$

Sokan came to ISU from Illinois Wesleyan University, where he had taught English and the humanities, having a master's degree in English. However, after some

\footnotetext{
${ }^{1}$ Samuel Edward Braden Presidential Papers, "Presidency Minutes, 1969-1970,” Dr. JoAnn Rayfield Archives, Illinois State University, Normal, IL.

2 JoAnn Rayfield File, "Illinois State University Mission Statement," Dr. JoAnn Rayfield Archives.

${ }^{3}$ James Cunningham, interview by author, Normal, IL, April 15, 2015.

${ }^{4}$ Memorandum by Joe Walker Kraus, April 6,1970, Joe Walker Kraus University Librarian (Dean) Papers, Dr. JoAnn Rayfield Archives.

${ }^{5}$ Ibid.
} 
years, due to a paralyzed vocal cord - unbeknownst to his physicians, he had a slow growing brain tumor - Sokan could not teach full time. He went to library school and earned a master's in library science from the University of Illinois with an emphasis in rare books, and archives. He was subsequently offered the position of special collections librarian at ISU. As the Special Collections librarian, his main duty was enhancing and caring for the rare books collection, which was his passion. The archival duties, which he knew were also part of his position, were secondary. ${ }^{6}$

During his time at ISU, the archives and Special Collections were located in the basement of the old Milner Library, presently Williams Hall. This was typical. In both the 1969 and 1972 surveys of college and university archives, the majority of archives were located in extra spaces, usually in the library, but basically anywhere on campus that had extra space. Even in 1969, there were serious environmental problems with the ISU library. Leaks were reported, as well as falling ceiling plaster due to those leaks. These conditions occasionally led to the destruction of materials and the need for conservation of materials affected by those conditions, such as leather and paper. Most of these problems occurred in the annex to Williams Hall constructed in 1964. The annex consisted of basement-to-roof metal library drawer shelving, connected across with metal support beams at the tops. Flooring was laid across those supports. There was a gap between the walls and the shelving, and when the roof leaked, this type of construction allowed water to flow down the walls all the way to the archives in the basement. That was a frequent occurrence in Williams Hall. Other leaks occurred due to air conditioning units and burst pipes.

In his first annual report, Sokan reported that "non-current papers [were] being

\footnotetext{
${ }^{6}$ Ann Sokan, interview by author, Bloomington, IL, February 4, 2015.
} 
transferred to the Library from University offices as time and space permit."7 Space and time, issues faced by many university archives, plagued ISU's archives as well. By the time the archives was created, Milner Library was already having to store little used books in other buildings, such as Stevenson Hall. Part of the problem was that, besides taking the records of the university, the archives accepted records outside of its scope such as correspondence of Hazel Buck Ewing regarding the suffragette movement, a collection from Mr. and Mrs. Charles Funk, a collection of letters describing the impressions of an emigrant from England, and papers from a number of Bloomington/Normal women's clubs. These records, while of local historical value, were more appropriate for a manuscript collection than for the ISU Archives and took up valuable space. Issues of time were reflected in the lack of adequate staffing - Sokan was the only trained archival staff - and Sokan's apparent disinterest in the archives.

Administrative policies were also detrimental to the growth of the archives at this time, as well as to the archivists' ability to obtain non-current university records. A report from the Sub-Committee on Storage and Access of University Papers to the Academic Senate in 1982 laid blame at the feet of past president David K. Berlo for the lack of an "extant operational archives policy." ${ }^{8}$ While I could find no reference to what specific action Berlo took that affected the archives, I can speculate, given the information on his presidency.

Berlo’s presidency ran from October 4, 1971 to May 30, 1973. During that time, Illinois was in the midst of a financial crisis. Governor Richard B. Ogilvie had slashed state universities' budgets, and Berlo saw this as an opportunity to "set the University on

\footnotetext{
${ }^{7}$ Robert Sokan, Annual Report, 1970, Records of Milner Library, Dr. JoAnn Rayfield Archives.

${ }^{8}$ JoAnn Rayfield File, "Illinois State University Mission Statement," Dr. JoAnn Rayfield Archives.
} 
a new course." $"$ Besides mandating a self-examination by all departments to determine how they would handle both budget cuts of 15 and 25 percent and a budget increase of 15 percent, Berlo immediately cut programs such as master's degrees in physics and determined to phase out others, like home economics teacher education. Berlo also cut the number of new teacher education majors who would be accepted, and he abolished the Student Services division.

While those changes were enough to cause unrest in faculty and staff, the change that I believe was the most detrimental to the archive's ability to collect non-current university records was Berlo's attempt to downsize the administrative arm of the college. Berlo believed that administration was top-heavy and needed to be overhauled. He wanted to establish a "two-tiered system."10 This system would have eliminated departments based on academic disciplines. They would have been replaced by "a dozen or so colleges or learning centers organized around broadly conceived programs. Faculty could be readily shifted...from one such administrative unit to another as student demand and societal need dictated." ${ }^{\prime 1}$ The colleges would be responsible for programmatic planning and administration would be responsible for budgets. Berlo began this plan in 1972, combining library science with speech communication, forming Information Science. He also combined home economics with industrial technology, a combination that really had no name that was "readily apparent to anyone."12

While Berlo did not get everything he wanted, he did manage to have colleges eliminated as fiscal units. So, on July 1, 1972, the college offices closed and the deans

\footnotetext{
${ }^{9}$ John Freed, Educating Illinois: Illinois State University, 1857-2007, (Virginia Beach, VA: Donning Co. Publishers, 2009), 326.

${ }^{10}$ Ibid., 328.

${ }^{11}$ Ibid., 328

12 Ibid., 329.
} 
"were moved to the fourth floor of Hovey and given university-wide responsibilities.

The departments were left to fend for themselves." ${ }^{, 13}$ In a report from the North Central Association, the accrediting agency for the college, the association found that faculty morale had declined, that the "University's administrative structure was in a 'state of evolution' with no clear plan for stabilizing the situation," ${ }^{\prime 4}$ and that department heads were "confused as to how to manage affairs because of the shuffling about of personnel and offices and the separation of program and budget control." 15

According to Roger J. Champagne, Berlo's administration of ISU

came at a time when one period of institutional development had ended and another was beginning, a change common to higher education generally. Dr. Berlo, like a number of other new presidents of the time was hailed as a "new breed of administrator, one who was catapulted from the academic ranks to the presidency...in order to restore campus peace and introduce fiscal accountability and managerial efficiency through strong leadership. But in the history of higher education, the so-called new presidential type actually represented a return to an older style of institutional leadership characterized by the authority and power of the president's office. ${ }^{16}$

With the Academic Senate set to pass a vote of no confidence, and plagued by accusations of fiscal misconduct, Berlo resigned in May 1973. The Board of Regents named Gene A. Budig as acting president, then in November named him the twelfth president of ISU. Budig quickly restored a "sense of administrative stability within the University"17 by reestablishing the collegiate and administrative structures.

Even with the return to normal, the chaos caused by this realignment and consolidation of power over that two-year period had lowered the morale of both faculty and staff, and made them more protective of their records. Why would the

\footnotetext{
${ }^{13}$ Ibid., 329.

${ }^{14}$ Ibid., 329.

${ }^{15}$ Roger J. Champagne, A Place for Education, Illinois State University, 1967-1977, (Normal, IL: Illinois State University Foundation, 1978), 110.

${ }^{16}$ Ibid., 113.

${ }^{17}$ Ibid., 115.
} 
administrators, deans, and secretaries want to give up their records to the archives? What would become of their records - even if they were not current - if they did turn them over to the archives? Would they be lost? Would they disappear somewhere? What if they needed these records to substantiate financial needs or enrollment numbers? Would they have access to them? This uncertainty and atmosphere of distrust had a far-reaching and long-lasting effect on the records management program at ISU which will be discussed in a later chapter.

In 1976, Milner Library, along with Special Collections, moved to their current location. But lack of space and time still plagued the archives, which remained in Williams Hall. During that year, the ISU Archives became part of the Illinois Regional Archives Depository system (IRAD), accepting the non-current records of twelve Illinois counties and receiving 278.5 cubic feet of material in $1977 .{ }^{18}$ The archives also accepted collections outside of its scope, such as materials from the League of Women Voters and papers from the Morgan-Washington House. Sokan's answer to lack of space would be to toss out an older box of records and replace it with the new box of records. ${ }^{19}$ That would be unthinkable now, but it was within Sokan's purview as archivist to dispose of records, and since ISU had no record retention schedule, Sokan could dispose of any records as he saw fit. I can only speculate what records he would have discarded, but randomly destroying records would have gone against any archival training he had. I would like to think that Sokan had much of the contents of the archive in his head rather than listed in catalogs or finding aids. Memory-based finding aids were one of earliest

\footnotetext{
${ }^{18}$ Robert Sokan, Annual Report, 1977-1978, Dr. Jo Ann Rayfield Archives.

${ }^{19}$ Cunningham, interview.
} 
finding aids and were in extensive use in the $1940 \mathrm{~s}^{20}$ It would be reasonable to believe that that may have been the case, considering Sokan's split duties and lack of staff. If he knew what those boxes contained and that they had no archival value, nothing was lost. If, however, the disposal really was random, there can be no estimate as to what history was lost.

With the addition of IRAD, Sokan gained two interns for staffing IRAD, whose positions were paid for by the State of Illinois. Those interns, however, were solely for IRAD; they did not do any processing of university records. Sokan did have one intern for ten hours each week to staff the reception area, once the library, and Sokan's office, moved to the new building.

In his 1982-1983 annual report, Sokan noted the overarching issue of a "lack of University administrative policy" that kept the archives in limbo. ${ }^{21}$ That lack of policy, which could be translated to neglect on the university's part, exacerbated the issues faced by the archives. The first issue was a lack of a library clerk trained in archival work to assist the archivist. A full-time clerk would have allowed the archives to remain open 40 hours each week rather than the 15-20 hours and allow for more collections to be inventoried. With only a part-time student worker, Sokan could do little except daily upkeep. Lack of staff precluded providing any sense of organization to the collections. He also suggested that a full-time archivist be hired. The second issue concerned the leaks and water damage that continued to occur. Sokan hoped that that issue would be solved soon. $^{22}$

\footnotetext{
${ }^{20}$ William Van Schreeven, "Information Please: Finding Aids in State and Local Archival Depositories," The American Archivist 5, no. 3 (July 1942): 170.

${ }^{21}$ Robert Sokan, Annual Report, 1982-1983, Fred McCrae Peterson papers, Dr. Jo Ann Rayfield Archives. ${ }^{22}$ Ibid.
} 
Sokan retired in 1987, with librarian Laura Gowdy replacing him as head of Special Collections and Archives, which had become two separate departments. Gowdy started her career at ISU as a cataloger in Milner Library in 1967. She moved into the Teacher Materials Center (TMC) in 1969 and stayed in that position until moving into Special Collections and Archives in 1987. Gowdy went into the position "totally unprepared. ${ }^{, 23}$ While she had a degree in library science, the only training she had for the archives was the auditing of one semester of an archives class at the University of Illinois after getting the archivist position.

Having a librarian as head an archives was not unusual, as revealed in the 1962 and 1966 surveys discussed in the previous chapter. While both a librarian and an archivist may both earn a master's degree in library science, the training for a librarian versus an archivist are different. Librarians learn to catalog books topically, while archivists rely on provenance and respect des fonds. Librarians also describe at the item level, i.e. each individual book, while archivists describe at the collection or series level, i.e. Papers of President Smith (collection level), or Papers of President Smith correspondence, meeting minutes (series level). One beginning level class on archives would not have adequately prepared Gowdy to head the archives any more than one class in business management would prepare an accountant to head a corporation.

During her time over the archives, the archives received records from IRAD, which was supervised by history professor Dr. Jo Ann Rayfield. But otherwise there was very little coming into the university archives from the offices and colleges around campus. When a government official came from Springfield, IL and explained that the university should be keeping its records, Gowdy sent out letters to the academic offices.

\footnotetext{
${ }^{23}$ Laura Gowdy, interview by author, Normal, IL, December 12, 2014.
} 
She received little cooperation, as "usually the secretaries kept their own stuff, thank you." ${ }^{24}$ The university was supposed to set up a record retention policy, but Gowdy stated that they never did while she was there. ${ }^{25}$

Besides the Berlo fallout, another factor was possibly at play in the reticence of faculty and staff to turn over their records to the archives. According to Henry J. Browne, secretary of the Society of American Archivists from 1955-1966, this reticence may be "based on a misconception that there is no distinction between the private papers which are a product of the personal activities of an official and the records which result from his work for the institution. These latter he has no right to destroy willfully or to keep, since they are institutional records and not his personal property." ${ }^{26}$ The staff seemed to view their respective department's records as their personal property to protect, and there was no university policy that stated otherwise. The archives did receive the papers from various retired faculty and staff, the archives of the Illinois Association of Middle Schools, copies of job runs from ISU Printing, scrapbooks from the local chapter of Delta Kappa Gamma, and alumni material. According to Gowdy, she processed these materials following the procedures she learned from the class she audited but could not recall specifics on how they were processed.

Staffing and space remained issues during Gowdy's tenure. Gowdy, overseeing both Special Collections and Archives, had her office in Milner Library, while the archives was still in Williams Hall. This arrangement caused a significant inconvenience to researchers desiring to use the archives, as well as a significant danger to archival

\footnotetext{
${ }^{24}$ Gowdy, interview.

${ }^{25}$ Gowdy, interview.

${ }^{26}$ Henry J. Browne, “An Appeal for Archives in Institutions of Higher Learning," The American Archivist 16, no. 3 (July 1953): 220.
} 
records. Should a researcher wish to use records from the archives for any length of time, they had to be retrieved from Williams Hall and transported to Milner Library. This was done in all kinds of weather, exposing possibly fragile records to detrimental conditions. The arrangement also caused the archives to be open only ten hours per week, the number of hours that student help was available in the archives. This led to a reduction of use, which in turn led to a reduction in hours, with Saturday hours being cut.

The environmental conditions in Williams Hall continued to deteriorate. Gowdy and Rayfield constantly battled water, heat, and mold. In one instance, Rayfield came into the archives in the morning to find the paint hanging from the ceiling "like icicles" and water all over the floor in the archives due to a ruptured steam pipe valve. ${ }^{27}$ Rayfield and Gowdy spent much of that day salvaging what they could. A number of IRAD records were lost during this incident. About a year or so later, in the evening, a building service worker noticed water in a classroom in Williams, used the shop vacuum to suck it up, left the classroom, then came back and realized there was more water. The worker notified the ISU police, who in turn notified Rayfield. Rayfield came into the archives and spent the entire night and into the next morning sopping up water, salvaging IRAD boxes which had been on the floor, removing Circus collection pieces from danger, and doing general clean up. Thankfully, the type of shelving used in the old stacks allowed for an inch deep trough that ran under the stacks, contained some of the water, but some items were lost or damaged during this incident.

The temperature in the archives ranged anywhere from 55 degrees to 85 degrees. The Society of American Archivists suggests a temperature range of 60 to 70 degrees

${ }^{27}$ Dr. Jo Ann Rayfield, phone interview by author, April 8, 2015. 
Fahrenheit. $^{28}$ But, since the College of Business occupied part of Williams Hall and needed heat for their offices and classrooms, the building was kept warmer. To keep the archives from getting too hot in the winter, the archives staff had to run air conditioners, and even that did not keep the conditions cool enough. The relative humidity in the archives also fluctuated tremendously from 25 - 30 percent in the winter to between 80 and 85 percent in the summer. ${ }^{29}$ Even with dehumidifiers on around the clock, the humidity could not be kept at an acceptable level.

Upon Gowdy’s retirement in 1992, Dr. Jo Ann Rayfield assumed the archivist position part-time, handling both University Archives and IRAD. Rayfield began at ISU in the fall of 1966 as an assistant professor of history, having her master's degree. She then earned her Ph.D. in history from Vanderbilt University in 1969. One of the things Rayfield loved about being a historian was doing research in archives, and having her own archives was "like winning the lottery." 30

But why put an historian in charge of the archives? Why not put another librarian in charge? After all, Rayfield's only experience with archives was doing research in archives in Latin America, and researching in an archives is much different than heading an archives. While there was no definitive answer in the papers in ISU's archives, I can only speculate as to the reasons. First, Rayfield was available and had been supervising the IRAD interns. Second, historians played a crucial role in establishing archives and the archival profession in the United States. According to Mattie U. Russell, J. Franklin Jameson, the first executive secretary of the American Historical Association, is known

\footnotetext{
${ }^{28}$ Guidelines for College and University Archives," Society of American Archivists, accessed June 8, 2015, http://www2.archivists.org/node/14805.

${ }^{29}$ Special Collections and Archives Task Force Report, 1998, Special Collections, Milner Library, Illinois State University, Normal, IL.

${ }^{30}$ Rayfield, interview.
} 
as the "Father of the National Archives." ${ }^{31}$ It was historians Jameson and Waldo Gifford Leland who pushed for a national archives, and it was a historian, Robert W. D. Connor, who was appointed to head the National Archives as the first archivist of the United States. T. R. Schellenberg, who held a Ph. D. in history, authored the first American handbook of archival administration, Modern Archives: Principles and Techniques, as well as The Management of Archives. Herman Kahn, one of the founders and presidents of the Society of American Archivists, stated

the training one receives as an undergraduate and graduate student in history or related subjects, which gives or should give one a knowledge of what scholarship is, what research is, how research is conducted - the relationship of the scholar to his sources, and the uses and limitations of various kinds of sources - the whole story of man, and as a part of that story, how man has used the record in writing his own story - all of those vast areas of human knowledge that make use of the written record - it is when he is being trained in these fields that the potential archivist is receiving the truly professional part of his training. ${ }^{32}$

Rayfield had already retired from her professorship, had been supervising the IRAD interns, and had been Sokan's choice for his replacement according to both Gowdy and Rayfield. With both her history and her archival research backgrounds, and her willingness to take the part-time archivist position, Rayfield was an obvious choice. She recognized her lack of archival administration knowledge and experience so she involved herself in archives discussion boards and listservs, attended conferences, and read extensively to become more knowledgeable about archives and to keep up with archival trends.

After taking over the archives, Rayfield found there was some order to it. Sokan had pulled together all the presidential papers, board papers, and colleges and department

\footnotetext{
${ }^{31}$ Mattie U. Russell, "The Influence of Historians on the Archival Profession in the United States," The American Archivist 46, no. 3, (July 1983): 280.

${ }^{32}$ Herman Kahn, "Some Comments on the Archival Vocation," The American Archivist 34, no. 1 (January 1971): 7 .
} 
papers, and placed each of those collections in rows, giving order to those major collections. But Rayfield faced major challenges in the neglected archives. Limited space, limited personnel, and poor conditions continued to be issues, as was gaining physical and intellectual control of the archives.

Williams Hall was plagued still by leaks, both from the way the annex was constructed as well as from broken pipes and dripping air conditioning units. A leak from the air handling unit on the fourth floor in August of 1995 caused minor splash damage to materials. Another leak from the fourth floor in August of 1996 caused water to cascade down the stairs between the third and fourth floors. In 1997, mold became a major enemy. In July, the archives and storage areas had to be closed for mold clean-up. Again in August, the archives closed for mold and water clean-up. In February 1998, disaster was narrowly averted. A leak from a broken pipe left several inches of water on the floor. Ten IRAD boxes were lost and the water had run into the cage that held the Circus Collection. Rayfield and IRAD interns were able to remove valuable items from the water's path, saving the collection from damage.

Heat and humidity problems still existed. The combination of heat and humidity created the perfect environment for mold growth. The Office of Health and Safety found mold levels so high in the summer of 1997 that the archives had to be closed to the public for a few weeks. Professional clean-up personnel had to wear respirators. ${ }^{33}$ A few months later, the archives again had to be closed due to mold. According to the Centers for Disease Control and Prevention (CDC), the Institute of Medicine (IOM) found there was "sufficient evidence to link indoor exposure to mold with upper respiratory tract symptoms, cough, and wheeze in otherwise healthy people; with asthma symptoms in

\footnotetext{
${ }^{33}$ Special Collections and Archives Task Force Report, Milner Library.
} 
people with asthma; and with hypersensitivity pneumonitis in individuals susceptible to that immune-mediated condition." ${ }^{34}$ Besides being a health hazard, mold is also one of the four primary causes of material deterioration in archives. ${ }^{35}$ In addition, many pipes were wrapped in asbestos and the ceiling had asbestos tiles, another known carcinogen.

Besides the poor environmental conditions, lack of space presented its own set of challenges. By the time Rayfield became archivist, the archives had run out of shelf space for presidential papers, ending with President Bone. Where would the succeeding presidents' papers - Braden, Berlo, Budig, Watkins \& others - be placed? Rayfield had to put things "wherever the hell you could find a place to put stuff." $" 36$ This, in turn, led to difficulties creating a shelf locator that was accurate and up-to-date for the collections, informing staff where each collection was located within the archives. Now, that would not be too difficult if, for example, all of President Braden's boxes were together, apart from the rest of the presidential papers, but if multiple boxes were scattered across the archives in various locations, it would have been both time-consuming and confusing. Imagine if one of the boxes had been placed in the incorrect location. That would lead to another box, possibly not of the same collection, being placed where the correct box should have been, and so on, creating a cascading effect that could wreak havoc in both the physical and intellectual control of the archives. Rayfield also wanted to maintain a relationship with the university community - faculty, staff and alumni - so she rarely turned down anything offered to the archives, adding to the already crowded conditions. ${ }^{37}$

\footnotetext{
34 "Mold," Centers for Disease Control and Prevention, accessed June 8, 2015, http://www.cdc.gov/mold/faqs.htm\#affect.

${ }^{35}$ Gregor Trinkaus-Randall, James Reilly and Patricia Ford, "The Massachusetts Experiment: The Role of the Environment in Collection Preservation," The American Archivist. 77, no. 1 (Spring/Summer 2014): 136.

${ }^{36}$ Rayfield, interview.

${ }^{37}$ Cunningham, interview.
} 
Her vision for the archives was that it would not only be a repository for ISU's noncurrent records with historical value, but also to be its institutional memory.

She confronted not only the problems of space for the archives collections, but also the overflow from Special Collections, which had been moved to the new library. If Special Collections did not have room for something, it was sent over to be stored in the archives in Williams Hall. The archives would have had use of what was called "the Cage," if some of the larger pieces of the Circus Collection and the overflow from that and other collections had not taken up that space. Not only did Special Collections take up some of the space, it also made more work for Rayfield. As she was going through archives boxes, it was not uncommon to find boxes and items from Special Collections, the Circus Collection and the Rare Books collection. Rayfield told of one day finding an unlabeled cubic foot box. She opened the box to determine what it contained. It was full of dolls. She had no idea to which, if any, collection this box belonged. She called over to Special Collections and asked if they were missing any dolls. They were not missing any dolls. There had not been room for the dolls in Milner, so they had been sent to the archives as overflow from the Lois Lenski collection, unlabeled. ${ }^{38}$

Rayfield also had the challenge of creating finding aids for the collections, building upon the foundation laid by Sokan. Some of the older collections had been processed to the item level, meaning that every letter, every memo, every note, had been described and listed in a finding aid. Others were described only to the collection level, meaning that if someone wanted to research, for example, President Bone's speeches, if the collection were processed at the collection level, the finding aid would have been listed something like: Robert Gehlmann Bone Presidential Papers, 1927-1991, 45 boxes.

\footnotetext{
${ }^{38}$ Rayfield, interview.
} 
While Rayfield knew where things were in the archives, even the unprocessed material, all that information was in her head. She wanted the collections inventoried and described at the folder level, giving more information about what each box contained, but not as much information as if they were processed to the item level.

However, she recognized that even with the best possible finding aids, if no one was using the archives, how could she justify its existence to the university? So, she set about building patronage and support at the same time as processing collections and writing finding aids. Rayfield went to various departments and asked if they knew what information the archives held for their departments. She then told them all about what the archives had, "kind of showing off about what [she] knew about their department."39 In this way, she garnered some interest from faculty and staff in the archives' holdings, turning to the archives to verify beginning dates of academic programs, departments and the like.

In the fall of 1997, the dean of University Libraries, Clifton Jones, established a task force to consider "whether or not the library should expand its existing Special Collections and Archives Program. ${ }^{40}$ The task force consisted of Teresa Thomason, Eloise Cline, Nancy Fry, Sharon Hartzell, Jo Ann Rayfield, Mildred Rjaden and Joan Winters. After approximately six months, the task force issued its report and recommendations. The report cited concerns regarding the archives' environmental conditions and lack of space. Its recommendations were as follows: have a full-time archivist; establish an effective records management program; expand the operating hours for the archives to a full day; and house Archives and Special Collections in the same

\footnotetext{
${ }^{39}$ Rayfield, interview.

${ }^{40}$ Special Collections and Archives Task Force Report, Milner Library.
} 
location with increased space.

Rayfield's work of obtaining faculty and staff papers and promoting the archives paid off through the preservation of some materials relating to the history of the university that would otherwise have been destroyed. One such collection was the Nelson Smith photographs. Nelson Smith served as university photographer from 1939 through 1991, capturing the history of ISU in photographs. Rayfield received a call from Jerry Liebenstein, the university photographer in Marketing and Communications at that time, telling her that the department had been given orders to put the photographs and negatives from Nelson Smith out on the curb by the end of the work day and asking her if she wanted them. Rayfield contacted a friend to help her, and they went over to Marketing and Communications and loaded all they could into her small Toyota pickup. She managed to get another day so she could complete the task. Within 24 to 36 hours, they moved all the negatives - at least 400,000, according to Rayfield's recollection - to Special Collections because that facility had climate control, and all the proof cards to the archives. These photographs are the archives' photographic collection, not just a part of it. If Liebenstein had not contacted Rayfield about these photographs, an irreplaceable photographic documentation of the University's history would have been lost.

The archives remained in Williams Hall battling the leaks and lack of climate control through 2008, when it moved to the facility at Warehouse Road in north Normal. The move was not an easy one, nor was it immediate. In 2003, one of Milner Library's goals was to move the archives to Warehouse Road, along with designing and constructing a secure area for the archives and funding and construction of a cold room. Those goals appeared again in 2004. 
The move did not start until 2007. Rayfield organized the move from Williams Hall. Packing began in the fall/winter of 2007 and the physical move began in January, 2008. It took months to move, as there was "way too much material to be done in one shot," according to Jim Cunningham, who worked two days each week in the archives from April 2006 through May 2010. The document cases were packed into boxes in order, and movers took them to the new facility. Besides the amount of material to pack, another hindrance was the lack of boxes. For every transport, Rayfield, directed the movers on the placement of the boxes. She, Cunningham, and Mark Schmitt, who also worked in the archives, would then unpack the boxes, place the document cases on shelving, then bring the boxes back to fill them up again. Rayfield could have used movers to do the entire job of packing and moving, which would have been faster and more efficient, but she "was very particular about who she would allow to even be in those spaces with that material, let alone touch it." ${ }^{\text {"4 }}$ Cunningham and Schmitt recall using their personal vehicles to transport boxes and individual items, such as the Civil War sword of ISU's first president Charles Hovey, to the Warehouse Road facility. Rayfield did not feel comfortable using University vehicles or movers for what she considered the most valuable items in the archives.

The move gave Rayfield the ability to bring order to the archives. Having more space allowed her to arrange the collections in the same structure as the university - the presidential papers, then colleges, then departments, etc. Her plan hit a snag when she realized she did not have the shelving she needed. Rather than purchasing new shelving, the library acquired excess shelving from Illinois Wesleyan. The shelves were placed back to back in the new archives, with the thought that document cases would be placed

\footnotetext{
${ }^{41}$ Cunningham, interview.
} 
on both sides. However, the shelves did not have the depth needed - a minimum of nine inches per side - to accomplish this. Milner Library already was using another part of the building for infrequently used books, and the shelving for those books was what Rayfield needed. She called over to the library and asked if she could swap out shelves. She got the okay, and began the labor-intensive task of removing the books, moving the larger shelf to the archives space, moving the smaller shelf to the library space, and placing the books on the smaller shelf. Rayfield's inexperience with archives is apparent from this incident, as an experienced archivist would have recognized that these shelves would be insufficient. She stated that the depth of the shelving was something "she didn't think about in the beginning. I guess because I thought someone else would.. ${ }^{42}$

Moving to a new space did not solve all of the problems and created a new one. Nearly a month after the move, Rayfield heard "plop, plop, plop" as she was working in the archives. ${ }^{43}$ The roof leaked. Plastic sheets covered the boxes and shelving, and buckets collected the rain water. Somehow, Facilities was able to find the money to repair the roof without the loss or damage of any documents. There were also mice living in the walls in between the archives and Property Control. Mark Schmitt, who worked in the archives from April 2008 through February 2010 as a full-time archivist specialist had the daily task of checking for mice when he arrived at the archives and would often find them. ${ }^{44}$ He would then call pest control and someone would come out and deal with them.

But a new challenge lay ahead for Rayfield after the move. "When you move the archives away from campus, it makes it harder for patrons to get there," stated Rayfield

\footnotetext{
${ }^{42}$ Rayfield, interview.

${ }^{43}$ Ibid.

${ }^{44}$ Mark Schmitt, interview by author, Normal, IL, April 15, 2015.
} 
regarding the drop in archives usage. It was difficult to justify the importance of the archives if it was not being used. Rayfield and her staff, Jim Cunningham and Mark Schmitt, had to make the archives more visible and accessible. Although Rayfield did not have the skills for digital asset management, Schmitt did. He and Cunningham began scanning images, with Rayfield at times identifying the people in the photographs. Digitization had been an archives' goal for some time. Beginning in the $2003-2004$ annual report, the archives was to continue migration from print to electronic records, including databases, monographs, periodicals and reference material, as well as to develop a plan for implementing a digital assets management program.

Rayfield also recognized that even if she had a world-class archives, it would not matter if it was not being used. She, Cunningham, and Schmitt answered many patrons' requests for photographs of friends or relatives who attended ISU. That required a lot of work, since the photograph collection did not have names attached to the photographs. Cunningham recalled that many times, if he received a request for a team member's photograph, he would start with back issues of The Vidette from the years the alumnus attended to find group photographs of the team listing the names, get a feel for what the person looked like, then go through individual head shots until he found one or more that resembled the person. He would then send the scans to the patron to determine if any of the photographs were correct. If so, he would then get the negative and have a print made. ${ }^{45}$ They also assisted patrons requesting aid with genealogic research, both from the archives and IRAD.

Departments also came out to look at their files for fund-raising efforts and centennial celebrations. Rayfield did not always wait for the departments to come to her.

\footnotetext{
${ }^{45}$ Cunningham, interview.
} 
For example, she knew that the Agriculture Department had its anniversary coming up, so she told Cunningham to pull photographs relating to the department, digitize them, and put them online. In that respect, she was proactive. "She had her finger on the pulse of the University," stated Cunningham. ${ }^{46}$

Rayfield retired in 2010, and Ross Griffiths, Director of Preservation and Archives at Milner Library, served as interim archivist. There was a question as to whether the archivist position would remain a part-time position or become full-time, but it was clear to Griffiths and "to anybody who was paying attention to archives that a parttime position was not adequate for the amount of work that needed to be done. ${ }^{, 47} \mathrm{Dr}$. Sohair Wastawy, Dean of University Libraries at ISU, made a decision and secured the funding for a full-time archivist.

Griffiths had the responsibility of crafting the job description and qualifications for the new archivist. He knew he wanted someone with two degrees - a master's of library and information science and a second subject master's, preferably in history. This double degree would keep the archivist on par with the rest of the library staff. With the archives already separated physically from the library, he wanted to keep any other separation as minimal as possible.

After interviewing several candidates, the librarythey extended an offer to April Karlene Anderson, who became the University's first full-time archivist of the Dr. Jo Ann Rayfield Archives on April 11, 2011. Anderson, who had a master's in library and information science and a master's in history, came to ISU from the University of Central Florida, where she had been senior archivist and an adjunct instructor in history. She

\footnotetext{
${ }^{46}$ Cunningham interview.

${ }^{47}$ Ross Griffiths, interview by author, Normal, IL, December 11, 2014.
} 
faced a daunting challenge: develop finding aids, as well as procedures and practices to catalog the collection.

When Anderson began, there was 12,000 linear feet in the archives, including negatives, flat files, and photo drawers, and approximately 250 collections. There were few finding aids and little intellectual control of the collection. Since that time, Anderson has "radically transformed the archives." ${ }^{48}$ She, along with archives assistant Jenna Self, interns, and student workers, have reinventoried and condensed nearly 100 collections down to 10,550 linear feet. Finding aids are now available for all processed collections and are available on the archives' webpage and through the Milner Library catalog.

However, those advances do not nullify the fact that the archives is housed in a sub-standard building according to archival standards. The Warehouse Road facilities are over 35 years old and have several factors that make them unsuitable for housing the archives. First, the staff have no control over temperature and humidity levels. While there are devices in the archives' stacks that measure both, all Anderson can do is collect the data but can do nothing to correct the levels should they fall out of the recommended range. There is also the issue of water. Although the leaky roof was replaced, Anderson has to battle water from another area. The building was built on a concrete slab and the drainage around the building is inadequate. Water pools outside of the building and seeps in under doors. Anderson has to keep absorbent tubes in front of the doors to prevent the water from infiltrating the stacks. Security is also a problem. Property Control, which occupies the other portion of the warehouse, had a theft over the winter. There had been one key type for the entire building, and one code that has been passed around to the employees there, as well as to Facilities and the building service workers.

${ }^{48}$ Ibid. 
There are no cameras in the Property Control area, and a single camera in the archives' stacks, focused on one area. The thief could have gained access to the stacks and the archives' office area.

The other problem the archives faces is its location. While much better than its previous location in Williams Hall as far as conditions, the location is a large obstacle. The archives is three miles away from the university, and the nearest city bus stop is about a mile away from the archives. While students can bike, walk, skateboard, etc. on Constitution Trail from the university or the bus stop to archives, bad weather or limited time can make that trip inconvenient for students without vehicles. Distance gives the archives a negligible presence on the campus. One of the most common things Griffiths and Anderson have heard is that people did not know ISU had an archives. To counter that, Anderson has made and continues to make outreach to the university community and its alumni through meetings, a blog, attending University events, presentations, and digitizing such items as yearbooks and old photographs and making them available on the archives' webpage.

The development of the ISU Archives and its challenges have exemplified the development and challenges of university archives presented in numerous books and articles, and supported by a number of surveys. The archives was established by decree of a university president and fell under the umbrella of the library, had librarians as its first archivists, and was housed in facilities that were not ideal for an archival repository. A lack of policy for obtaining official university records led to difficulty in obtaining those records, and a lack of staff hindered the processing of existing records, as well as those coming into the archives. 
With such a past, what does the future hold for ISU's archives? Griffiths is exploring some major initiatives for the archives. He would like to see the digital collection grow, but first the archives has to develop the capabilities to collect digital materials. Because of the archives' lack of technology, the capacity to collect digital materials is limited. The other initiative, the "holy grail of the next couple of years," is to have the archives located on campus, adjacent to the library. Griffiths also recognizes that Anderson is still grappling with a tremendous backlog of collections to process, new records to accession, and finding aids to create. Added to those tasks are her outreach efforts. Griffiths would like to add another full-time staff member to process collections and supervise the interns and student workers in order to free Anderson for outreach activities. With the budget issues facing state universities in Illinois, it remains to be seen what goals will be met in the coming years. 


\section{CHAPTER III HISTORIES OF THREE STATE OF ILLINOIS UNIVERSITIES}

The three other Illinois universities I examined were Southern Illinois University at Carbondale (SIUC), Eastern Illinois University (EIU), and the University of Illinois (U of I). SIUC has a student body of 17,989 and does not have a degree sequence relating to archives. EIU is the smallest of the universities, having an enrollment of 8,913 students, and has a historical administration graduate degree that includes an introductory class on archives. $U$ of $I$ is the largest of the universities, with an enrollment of 44,520 students, and has a graduate degree in library and information science with numerous classes relating to archival practices and processes.

Besides the size of the student body and the archive-related courses or degrees, other factor may play a role in the development and support of the archives. The location of the university is one of the factors. For example, both SIU and EIU of the universities are fairly isolated, but one is located in an area near a national forest, and has numerous historic sites and museums, two wine trails, and a number of national chain hotels. The other has a few attractions, a nearby state park, and three hotels/inns. The other two universities, ISU and U of I, are located at the intersection of major interstates. The founding date could also be a factor, coupled with its administrator during its infancy. One university had a full-time archivist from its beginning, while another has had only part-time archivists. 
Southern Illinois University at Carbondale was established in 1869 and was the second teacher's college in Illinois. Carbondale is located in southern Illinois, about 16 miles from the nearest interstate, and has a population of 26,363. It is a rural setting, with much of the area part of the 240,000-acre Shawnee National Forest. SIU's 2014 audit showed revenues of \$209 million and expenses of \$199 million, with a positive balance of $\$ 10$ million. Its main campus is comprised of 1,136 acres. SIU offers 103 undergraduate degree programs, 78 graduate degree programs, and 34 doctoral degree programs, with no courses in archives or archival administration.

SIU's library opened in the same year as the university, 1869. Dr. Robert Allyn served as both president and librarian. ${ }^{1}$ The original library burned to the ground in 1883. Until a new building was constructed in 1903, the library shared space in other buildings. On June 7, 1904, the new Wheeler Library was dedicated. The university attempted to secure funding for a library/museum in 1938, but no state funds were appropriated for that project. In 1953, construction on a new library building began and the current Morris Library opened its doors in January, $1956 .{ }^{2}$

With the opening of a new library came new opportunities. A Treasure Room became the newest addition to the library, housing SIU's special collections. Those collections included rare books, examples of fine printing, rare items on Illinois history, and other works that required special care. ${ }^{3}$ Each year, more items were added to the Treasure Room. In 1956, seventeenth-century prints, a collection of gift annuals and

\footnotetext{
${ }^{1}$ Delores M. Manfredin, “A History of the SIU Library, 1874-1950,” Ralph E. McCoy Papers, Special Collections Research Center, Southern Illinois University, Carbondale, Illinois.

${ }^{2}$ Ralph E. McCoy Papers, Special Collections Research Center.

${ }^{3}$ Ibid.
} 
early American humor were all transferred to the Treasure Room. ${ }^{4}$ The Treasure Room housed a manuscript collection rather than a university archives at this time and was basically the university's special collections. Collecting local historical artifacts and photographs, such as the Coal Mining in Southern Illinois collection, was their focus. Any university records that were not lost in the fire or destroyed by poor conditions from being stored in basements and storage areas were held in offices.

There was no concerted effort to retain important and historic university records. But change was coming with the appointment of Kenneth Duckett, former curator of manuscripts for the Ohio Historical Society, as university archivist and manuscript curator in 1965. Dean of Library Affairs Ralph E. McCoy stated that "as University archivist, Duckett [would] devote a portion of his time to gathering and cataloging noncurrent records of the University itself.",

In "A Report on the Growth and Development of the Libraries at Southern Illinois University," Duckett noted that in 1966 a number of university records had been processed, including those from the Office of the President - 1916-1965, the Vice President of Operations - 1960-1964, and Student Government, as well as faculty papers, private papers, local history papers (labor records of Sahara Coal Company), oral histories, SIU pictorial history, and university publications. The archives was now collecting both university records and local history records as well.

In 1970, SIU began the Special Collections unit within Morris Library, led by McCoy. Four departments were housed under this umbrella - Rare Books, Manuscripts, University Archives and Illinois Regional Archives Depository (IRAD), with Duckett

\footnotetext{
${ }^{4}$ Ibid.

${ }^{5}$ Ibid.
} 
serving as both archivist and curator. While working at SIU, Duckett authored Modern Manuscripts: A Practical Manual for Their Management, Care and Use, an often-quoted primer for archivists and curators. He may be best known for his controversial role in preserving the Harding-Phillips love letters from probable suppression or destruction by the family of President Warren G. Harding. The letters were released by the Library of Congress in July 2014.

In 1980, Duckett retired from SIU and went to work at the University of Oregon. David V. Koch replaced him as archivist/curator. He oversaw the archives, which included "all papers that have a legal or historical relevance to SIU-C, from Board of Trustees minutes to old editions of The Obelisk, the SIU-C yearbook...copies of all theses and dissertations written by SIU-C students and most of the research papers written by faculty."6 Koch spent ten years as a rare book librarian before taking the reins of Special Collections. During his tenure, Koch "built upon the earlier work of both McCoy and Duckett in enlarging and enriching the collections." ${ }^{7}$ Under his guidance, the Special Collections unit was renamed the Special Collections Research Center (SCRC) in 2002.

During Koch's time over the SCRC, the university began to expand its collection of political papers of local, regional, state, and national significance. The papers include those of U. S. senators Paul Simon and Roland Burris, U. S. representatives Ken Gray and Glenn Poshard, Illinois representatives Kenneth Buzzbee and Jeanne Hurley Simon, as well as St. Louis mayor Clarence Harmon. Records from the League of Women Voters, the Peace Coalition of Southern Illinois, and the Carbondale Foundation for a

\footnotetext{
${ }^{6}$ Ibid.

${ }^{7}$ Gordon Pruitt, "David Koch Retires at July's End," Cornerstone 1, no.1 (Fall 2005): 5, accessed April 25, 2015, http://opensiuc.lib.siu.edu/cgi/viewcontent.cgi?article=1012\&context=morrisnews_cornerstone.
} 
Better Environment are also included in this collection.

Koch retired in 2005. In 2006, Pamela Hackbart-Dean was named as head of the Special Collections Research Center, "a vast collection of rare books, manuscripts, correspondence and photographs. The center also holds the University archives, made up of past legal and historical records of SIUC." " Hackbart-Dean, former head of special collections at Georgia State University and director of the Southern Labor Archives, wanted to increase the profile of the research center though outreach and publicity. At the same time, the university hired Leah Agne Broaddus as a library faculty member as well as archivist, relieving the director from archival duties for the first time.

In describing her duties, Broaddus, a graduate of Indiana University Bloomington with a library science degree, stated that "SIUC has been collecting boxes of archival material for years and storing them diligently. My job is to open the boxes, figure out what is in them, where it comes from, and how it can be saved." Her focus was not divided among collecting local history, rare books and manuscripts, and university papers, as previous archivists' attention had been. Broaddus could devote her time to unpacking, arranging, and describing the records of the university. She also helped steer the archives though a move from Morris Library while it was being renovated and then back to the new space. Hackbart-Dean, Broaddus and the archives staff took the opportunity to deaccession or weed out old the collection prior to the move back to the renovated library. ${ }^{10}$

\footnotetext{
${ }^{8}$ Tim Crosby, "Director of Special Collections Named for Library," News, June 16, 2006, accessed April 25, 2015, http://news.siu.edu/2006/06/061606tc6129.php.

9 'Focus on Library Faculty: Leah Broaddus,' Cornerstone 3, no. 3 (Spring 2000): 10 accessed April 25, 2015, http://opensiuc.lib.siu.edu/cgi/viewcontent.cgi?article=1002\&context=morrisnews_cornerstone.

${ }^{10}$ Pamela S. Hackbert-Dean, Leah Agne, \& Julie Mosbo, "History on the Move: Relocating Special Collections and Archives," (January 2010): 49, accessed April 25, 2015, http://opensiuc.lib.siu.edu /morris_articles/57/.
} 
Those moves had their share of difficulties and errors. For instance, upon their final inspection of the temporary space, they discovered that 45 - 60 boxes had either been inadvertently left behind or had not been included in the moving plan. They also discovered that the moving manager had instructed the movers to disregard spacing directions, leading to 6,000 boxes that had been shelved with no allowance for growth. ${ }^{11}$ Once that crisis was overcome, they found that the movers had placed adhesive tags on the outside of boxes and some of the larger items, like leather-bound books, that had been moved. The Preservation Unit trained a staff member to safely remove the tags with microspatulas and special erasers. ${ }^{12}$

Broaddus left SIUC in 2011 and was replaced by Matt Gorzalski in August 2012. Gorzalski came to SIUC from the History Center in Diboll, Texas, where he had been archivist. He had a master's in library and information science and a BA in history, and he brought with him experience in digitization and database design. ${ }^{13}$ Since his hire, he has made considerable progress dealing with electronic records, allowing the archives to accession and store them. They are currently taking data off of legacy media, film, tape, photographs, etc. The next step will be the migration from obsolete file formats and media. $^{14}$

As for the archives themselves, the SIUC archives uses stationary shelving in the archives for the archival boxes, while moveable shelving holds the rare book collection. Devices for monitoring humidity and temperature are located throughout the archives and checked and recorded by the preservationist librarian. Variances in temperature and

\footnotetext{
${ }^{11}$ Ibid., 51.

${ }^{12}$ Ibid., 51.

${ }^{13}$ Gordon Pruitt, "Matt Gorzalski Names University Archivist," Cornerstone 7, no. 4 (Summer 2012): 10. http://opensiuc.lib.siu.edu/morrisnews_cornerstone/27/.

${ }^{14}$ Matt Gorzalski, interview by author, Carbondale, IL, November 25, 2015.
} 
humidity can be corrected by the Physical Plant. Leaks, mainly from older pipes have presented problems in the past, but there have been no water issues since he arrived in $2012 .^{15}$

Just as with many archives, space and staff are issues. "We have a lot of space, but we're filling up fast," stated Gorzalski. ${ }^{16}$ He estimates that the archives currently holds about 20,000 cubic feet of records. He has been able to create more space through reappraisal and deaccessioning. Even so, the Special Collections Research Center has to use off-site storage for some unprocessed manuscript and political papers, as well as for theses and dissertations. Gorzalski has one assistant to help with archival duties. He also has interns and graduate assistants who help with reference services, front desk work, processing collections and writing finding aids. But to get through the backlog of collections, he estimates it would several years at the current level of staffing. ${ }^{17}$

The collections are particularly strong beginning in the 1940s through the present. Any collections prior to that time are "hit-or-miss," 18 due to the lack of care, lack of a collection policy, and lack of recognition of the importance of the records. Most of the collections are described to the folder level. Some collections, like the Richard F. Peterson Papers and the Thomas Frank Barton Faculty Papers, are described, at least in part, to the item level. Still others, like those of the various colleges, i.e. College of Engineering and Technology, College of Human Resources, etc., are described only to the box level. The collections that have been processed have finding aids available through Archon, an online searchable finding aid database, developed by Christopher

\footnotetext{
${ }^{15}$ Ibid.

${ }^{16} \mathrm{Ibid}$.

${ }^{17}$ Ibid.

${ }^{18}$ Ibid.
} 
Prom, assistant university archivist at the University of Illinois. Unprocessed collections are also listed, although with no information other than a name, the type of material, and the extent of the holdings.

While the acquisition of non-current records for some departments is spotty and inconsistent, other departments, such as the Theater Department, the Chancellor's Office and the Provost's Office, "value their history more," and thus the archives has more documentation on them. ${ }^{19}$ But overall, Gorzalski is "impressed with the amount and thoroughness of [their] holdings documenting the university and the frequency at which records are accessioned.",20

Eastern Illinois University was founded in 1895 in Charleston, Illinois, home to 21,961 people. Its campus consists of 320 acres, about ten miles east of the nearest interstate, I-57, which runs north to Chicago, and 18 miles north of Interstate 70, which runs east to Indianapolis, Indiana. The area surrounding Charleston consists of mainly of farmland. As of the 2014 audit, EIU showed revenue of $\$ 72$ million and expenses of $\$ 75$ million, leaving it at a deficit balance of $\$ 3$ million. The university offers 49 undergraduate degree programs, and 29 graduate degree programs, including one in historical administration, which provides an introductory course in archives.

According to retired EIU archivist Robert V. Hillman, EIU's archives officially began in 1989, when planning for the university's centennial was beginning. Yet a 1972 list of college and university archives from the Society of American Archivists lists EIU as having an archives that was established in 1967 with 147.7 feet of records, headed by University Librarian B. Joseph Szerenyi, who was director of library services and dean of

\footnotetext{
${ }^{19} \mathrm{Ibid}$.

${ }^{20} \mathrm{Ibid}$.
} 
library science. ${ }^{21}$ He retired in 1978. In a search of EIU's online database, there are no holdings for Szerenyi, and a search of EIU's website brought up little information except a commemorative program with his photograph, other archival photographs, and his death notice in the EIU Annuitants Association Newsletter. So, there was some sort of archives that collected university records prior to Hillman, but from the information Hillman provided, the records in the archives were not accessioned or in any kind of order.

When EIU hired Hillman in 1989 as a reference librarian, those records were in boxes, several hundred of them. Sorting through these boxes and making sense of the chaos became his job. The university needed someone to organize the files and help the historian pull together items for the centennial book that he was writing. Hillman held a BA in English and an MA in cultural studies, along with a master's in library and information science. Since Hillman had taken courses in archives at Brigham Young University while earning his MLIS, he was assigned as the university archivist. ${ }^{22}$ Prior to Hillman, EIU had had no archivist of any sort.

For much of his time as archivist, Hillman was a one-man show, and his time was split between Booth Library's reference desk (10 hours per week) and the archives (27 hours per week). ${ }^{23}$ However, if he was needed at the reference desk, the time he could spend in the archives was reduced by that amount. He did have some student workers and interns in the archives, but they were limited in what they were able to do since Hillman had to supervise them. They mainly manned the reception desk and added

${ }^{21}$ Society of American Archivists Committee on College and University Archives, College and University Archives in the U.S. and Canada (Ann Arbor, MI: University of Michigan, 1972), 13, accessed June 14, 2015, http://babel.hathitrust.org/cgi/pt?id=mdp.39015071441235; view=1up;seq=1.

${ }^{22}$ Robert V. Hillman, interview by author, Charleston, IL, March 9, 2015.

${ }^{23}$ Hillman, interview. 
records to collections already processed. In 2009, Hillman received an assistant, Johna Von Behrens. She helped process a number of collections and create on-line finding aids. She left in May 2014. Hillman retired soon after, in December 2014.

After Hillman's retirement, Bill Schultz was named interim head of archives. Schultz was hired in 1995 as a catalog librarian. Although he is the interim archivist, Schultz spends most of his time as a catalog librarian and in collections development. $\mathrm{He}$ is able to devote about one day each week specifically to the archives, and that can be reduced due to absences, meetings, and other duties as might be assigned. Schultz also supervises the Illinois Regional Archives Depository (IRAD) interns and one student worker. The student worker mainly focuses on utilitarian projects, such as weeding collections, about eight to nine hours each week, leaving Schultz with all other archival duties and not enough time to do more than tread water. At times, history or archival students will devote time in the archives as part of a class project. One such project involved a large-scale inventory of the stacks.

EIU's archives was not what I expected. Since the university has a graduate degree in museum studies with a course in archival administration, I thought the archives would be at least on par with ISU's and SIU's archives. However, that was not the case. Throughout the archives unit, unprocessed boxes of records are stored in cabinets and shelving along the walls, on long work tables in a corridor, as well as in the workroom. The archives room itself is located in the basement of Booth Library in a small, lowceiling room. The room is controlled for temperature and humidity, with devices placed in various locations. It is an L-shaped room, approximately 28 feet long by 56 feet wide, with the leg being approximately twenty feet by twenty-four feet. The ceiling is about 
seven feet high. There was no fire suppression system in the archives, and pipes ran along one of the walls. The left side of the room has nine mobile shelving units, while the right side has eight mobile shelving units, each approximately twelve feet in length and two feet wide. In addition, at the entrance of the room to the left, there are approximately four rows of smaller shelves housing the rare books. More shelving for rare books is located in the leg of the room.

Few of the collections have been processed and few finding aids are available online or though the library's catalog. Inventory lists are paper copies available in the archives. The finding aids that are available online vary in description. Some, such as the papers from the Office of the President, 1899-1933, are fully described to the item level. Others are described to the folder level, and many to the box or series level. Others, like the Eastern Illinois University Centennial collection, have no description at all. With the time available to him as interim head of archives, Schultz is just trying to "keep things afloat," until the university hires an archivist. ${ }^{24}$ Given the financial situation, Schultz does not anticipate that an archivist will be hired in the near future, if at all. $^{25}$

While EIU's archives is struggling along, The Keep, EIU's open access electronic institutional repository, provides online access to faculty papers, administrative records, special collections, historic photographs, conference materials, and exhibits, as well as EIU's yearbooks, senior scrapbooks, and master's theses. The Keep, administered by Booth Library but separate from the archives, was launched in 2012, and has over 30,000 documents available at a click of a button. According to a press release, The Keep tries

\footnotetext{
${ }^{24}$ Bill Schultz, interview by author, Charleston, IL, March 9, 2015

${ }^{25}$ Ibid.
} 
"to include what we think will have an impact historically. This includes information and images from EIU exhibits, conferences, video lectures, podcasts, posters, brochures, newsletters and press releases, as well as hundreds of photos and documents from University Archives."26 EIU invested in a scanning center consisting of three Fujitsu scanners and is staffed full time by the Institution Repository Librarian Todd Bruns, civil service staff, and student employees. Many of the scanned documents have come from EIU's archives. I believe that because of its rural setting, with little to draw researchers, EIU library administration saw The Keep as a way to promote its holdings more readily than through a conventional archives. The records are scanned and placed online. There are no archival supplies to purchase, no time "wasted" in foldering and labeling, no worries about writing a finding aid, and no space or environmental issues. Professors and students can easily upload their work to the site without contacting an archivist or filling out forms, and it can be done from wherever there is an Internet connection.

The University of Illinois was founded in 1867 in Champaign-Urbana, Illinois, which has a population of 125,176 . Its campus consists of 785 acres, about just a few miles from Interstate 57, which runs south from to Chicago, Interstate 72, which runs west to Hannibal, Missouri, and Interstate 74.which runs east to Indianapolis and west through Bloomington-Normal to Iowa. The area surrounding Champaign-Urbana is rural, dotted with small towns. As of the 2014 audit, U of I showed revenue of $\$ 3.5$ billion and expenses of $\$ 5.3$ billion, leaving it with a deficit of $\$ 1.8$ billion. The university offers over 150 programs of study, over 100 graduate degree programs and concentrations, including one in library and information science, and eighty-two doctoral

\footnotetext{
26 “EIU's Electronic Repository, The Keep, Reaches Patrons Worldwide,” Eastern Illinois University Media Relations, August 1, 2013, accessed June 16, 2015, http://castle.eiu.edu/media/viewstory.php?action=880.
} 
programs, including one in library and information science.

The University of Illinois (U of I) had pondered establishing an archives for many years. In 1920, the Subcommittee of University Archives called for the establishment of a "Central Office of University Archives to organize older records not essential to the transaction of business in administrative offices." ${ }^{, 27}$ The subcommittee also recommended the establishment of another committee, the Standing Committee on University Archives, to assess, inventory, and recommend an appropriate organization for older records, and records created after 1904, under the direction of a university $\operatorname{archivist.~}^{28}$

The administration recognized that unless something was done, the chances of valuable historical documents would be lost or destroyed. They noted that there had been a report that former university president Andrew S. Draper had "all previous (to 1894) correspondence destroyed with the exception of a single letter book which somehow escaped." ${ }^{29}$ President David Kinley did not act on these recommendations. However, a university librarian, Phineas L. Windsor did act. Windsor, "an instinctive collector," began assembling university publications in "The Illinois Collection," and stored faculty papers in various nooks in the new library, finished in $1926 .{ }^{30}$

In 1946, the university hired Dr. Icko Iben as newspaper librarian and archivist. This signaled that the administration was realizing the importance of archives and preserving the university's history. By 1962, Iben reported that the library, home to the archives, held nearly 1,000 cubic feet of unprocessed archival material and another 1,790

\footnotetext{
${ }^{27}$ Maynard Brichford, "The Illiarch," in College and University Archives: Selected Readings, (Chicago: Society of American Archivists, 1979, 19.

${ }^{28}$ Ibid., 19.

${ }^{29}$ Ibid., 19.

${ }^{30}$ Ibid., 20.
} 
cubic feet in offices around campus. ${ }^{31}$ This number was much lower than it should have been, considering that a survey of 100 university offices in 1953 found that there were "over 57,000 cubic feet of archival material.",32

In 1957 as the university began preparing for its centennial, history professor Arthur Bestor, chair of the Committee on the Centennial History of the University, continued to press for the establishment of an archives. In 1962, the university hired a part-time archivist, Susan Shattuck, to start organizing the records of the archives. Then, after forty-three years, in September 1963, the university hired its first full-time archivist, Maynard Brichford, and, through presidential notification, the University of Illinois formally established its archives.

Brichford found that although many records had been stored in attics, basements, and other campus buildings, there had been no significant loss of records. ${ }^{33}$ The records were gradually moved to their new home in room 19 in the basement of the University Library. Like many archives located in renovated basement spaces, the archives was plagued with water seepage, leaking pipes, varying temperature and humidity conditions, and mold issues. ${ }^{34}$ Those conditions did not deter Brichford from continually adding to the collection.

By 1979 , the archives was reaching its capacity of 4,656 cubic feet. They desperately needed more space. In 1985, a reading and search room was added to the archives, allowing more shelving to replace tables. Improvements in lighting and climate control were also implemented. Still, the archives lacked the space to adequately house

\footnotetext{
${ }^{31}$ Ibid., 20.

${ }^{32}$ Ibid., 20.

${ }^{33}$ Brichford, 20.

${ }^{34}$ William Maher, interview by author, University Library, University of Illinois, Champaign, Illinois.
} 
new accessions. Four off-site storage areas were in use by that time to house unprocessed records.

These records included records of student organizations as well as non-current university records. Since space was an issue, the university planned to build or acquire new space to house the archives if it could raise the money. That did not happen. Records had to be stored off-site at four different facilities, causing "increased costs and loss of efficiency in operations." 35 The archives continued on in its cramped quarters, with 99 percent of its 10,564 cubic feet of storage space occupied, until an opportunity arose to effectively split the archives. ${ }^{36}$

In 1989, the Student Life and Culture Archives (SLC) was founded through an endowment from the Stewart S. Howe Foundation. The SLC "actively documents the history and traditions of student life and culture at the University of Illinois through alumni and student papers (including diaries, scrapbooks, correspondence, and photographs), student organization records, administrative office records, oral histories, and student publications." ${ }^{, 37}$ This allowed for the transfer of student life-related records to the new Archives, relieving some of the space issue.

SLC is housed in the Horticulture Field Laboratory building, just over a mile away from the main archives. The space is very functional for the archives, since the records vault is basically a 3-story cement cube surrounded by hallways with office space and workrooms opposite it. The vault had been a storage bin for apples from the university's orchard, so it was constructed to be cool. While the temperature may have

\footnotetext{
${ }^{35}$ Brichford, 23.

${ }^{36}$ William J. Maher, “The Illini Archives: A Laboratory for Retrospective Research,” Illinois Libraries, 63, no. 1 (March 1981): 270.

37 “About," Student Life and Culture Archives, accessed April 27, 2015, http://archives.library.illinois.edu/slc/about-2/.
} 
been cool, there was still a need to have the archives vault retrofitted for temperature and humidity control, as well having archival shelving installed. The main floor and basement house the SLC collections, including the oral histories, while the third floor holds the records of the American Library Association (ALA). There are also parts of the Sousa collection, mostly large instruments, housed at SLC, as well as national association archives for such entities as the Advertising Council, American Association of Law Libraries, and the Third Armored Division Association.

SLC archivist Ellen Swain stated that 60 percent of all archives material is housed in the Horticulture Building. ${ }^{38}$ While she was unable to provide dimensions for the three vaults, the vault on one floor alone was larger than any of the archives examined. Swain has one full-time staff member who has experience in archives and who is able to aid in outreach, reference, electronic records, and class visits. This position is relatively new, having started in 2014. Prior to that, the position had been filled by a staff member who was interested in archives but with no experience or background in archives. Swain has two graduate assistants, one who works with the ALA archives and one who is specific to the Alpha Tau Omega archives. There are also three undergraduate students working in the archives.

U of I is also home to the Sousa Archives, which "acquires and preserves significant archival records and historical artifacts in multiple media formats that document America's local and national music history and its diverse cultures.."39 This archives was not included in this study, as it fell outside the realm of the type of university archives being examined.

\footnotetext{
${ }^{38}$ Ellen Swain, interview by author, Student Life and Culture Archives, Champaign, IL, March 18, 2015. 39 "About," Sousa Archives and Center for American Music, accessed April 27, 2015, http://archives.library.illinois.edu/sousa/about/.
} 
U of I archives houses other collections outside the scope of university records. Some national Greek fraternity and sorority organizations, through an agreement with $\mathrm{U}$ of I, have deposited their collections in the U of I archives. These collections, such as the Phi Eta Sigma and the Pi Alpha Phi records, are overseen by U of I graduate students. Other national organizations have also deposited their records with the university archives. Those include organizations like the Council of Planning Librarians, the Art Libraries of North America, the National Council of Teachers of English, and the American Society of Cybernetics. Local and state collections include the Cahokia Mounds collection, Champaign County Greenways and Trails Committee Records, and Chicago, Paducah, and Thebes Railway Company Journal, 1912-1914 collection. These collections, while not records of the university, are tied to papers or projects written or conducted by U of I staff and students.

While space was, and still is, a problem - three off-site storage facilities are currently in use - staffing was at least better than many other state university archives in Illinois. In 1979, the archives staff consisted of a full-time archivist, a full-time office person, four part-time graduate students and three part-time undergraduate students. ${ }^{40}$ By 1981, the staff had increased to include a half-time assistant archivist. ${ }^{41}$ As of 2015, the archives staff consists of the university archivist, an assistant archivist, an archivist for electronic records, an archivist for reference and user engagement, an archival reference and operations specialist, two visiting archival reference and operations specialists as well as a number of graduate and undergraduate students.

The abundance of staff - in comparison to the other three university archives

\footnotetext{
${ }^{40}$ Brichford, 23.

${ }^{41}$ Maher, 270.
} 
examined - and a minimalist processing philosophy, which will be discussed later, allowed for the accession and processing of a majority of their collections. Between 1974 and 1979, the staff was able to reduce the total percentage of unprocessed records from 71 percent to 4 percent. $^{42}$ In 1980 , the archives contained 8,764.1 cubic feet of processed records, and 233.4 cubic feet of unprocessed records (2.6 percent). That total jumped substantially over six years, with the archives holding 11, 592.2 cubic feet of processed records and 558.9 cubic feet of unprocessed records (4.6 percent). ${ }^{43}$ The percentage has fluctuated over the years, but the backlog is not something Swain sees as being resolved in the near future. ${ }^{44}$

The $\mathrm{U}$ of I archives also has the ability to store and preserve digital records. This collection holds three terabytes of electronic records. ${ }^{45}$ To put that into perspective, a 74 minute CD contains 650 megabytes. ${ }^{46}$ One terabyte is equal to $1,048,576$ megabytes. That means that 1,613 74-minutes CDs would be needed to hold one terabyte of information. The U of I archives would need 4,839 74-minutes CDs to hold all its electronic records. Stacking those CDs would result in a tower nearly 16 feet tall. Burning songs onto those CDs, assuming the average song is five minutes long, would result in over 71,500 songs.

What is in store for the University Archives? The main archives is due to move to a larger space in May 2015. The new archives will be located on the first floor of the University Library and will provide another 1,400 cubic feet of space and better climate

\footnotetext{
${ }^{42}$ Brichford, 26.

${ }^{43}$ William J. Maher, "The Illini Archives in the 1980s," Illinois Libraries 69 no. 4 (October 1987): 584.

${ }^{44}$ Swain, interview.

45 "University of Illinois Archives: Bringing History to Life," University of Illinois, accessed April 27, 2015, http://archives.library.illinois.edu/.

46 “Technology Q \& A,” Optical Storage Technology Association, accessed April 27, 2015, http://www.osta.org/technology/cdqa8.htm.
} 
control. Included in the new space is an improved public service space and a conference room. The basement location will still house much of the collections, while the most used collections will be moved to the new space. The SLC received a \$1.1 million grant for the replacement of its environmental system in all three vaults and for the installation of a fire suppression system in the vaults. Construction is also underway at SLC for a new vault to house overflow instruments from the Sousa Archives.

It does appear that location, size, degree offerings, as well as the archive's first administer had an effect on the development of these archives. U of I and SIU both have other historical sites and museums in the area for researchers, as well as leisure activities should the researcher be inclined to partake of them. What person would not like to be able to tack a day onto his or her stay in an area to explore some part of the area he or she is visiting? Or maybe the researcher has brought along family to make the trip a business/vacation. There is also an abundance of lodging in both areas, making attending events like Homecoming easier for those who live out of state and want to return to their alma mater and relive the history and traditions they hold so dear. That kind of support, with some outreach from the archivist, leads to additions to collections. In U of I, the hiring of a professional full-time archivist at the founding of the archives meant that records were not left in boxes for some poor archivist in the future to find and deal with. The records were instead processed according to archival protocol the first time. 


\section{CHAPTER IV}

\section{RECORDS LOST: THE NEED FOR AN ACTIVE RECORDS MANAGEMENT PROGRAM}

One thing that all these university archives have in common is the need to preserve records of legal and historical value. Prior to having archives, the preservation of those records was haphazard. Very few people think of the records they are creating in the present from a future perspective. That letter from the university president to the women's dean discussing the women's curfew, the resolution from the Student Government calling for a full week's break at Thanksgiving, the email from the dean of the college to a chair discussing possible cuts in classes - the record creators knew that any action resulting from those communications would have an effect on university life but rarely believed that those letters, resolutions, or emails had value enough to be preserved. The creators were thinking in the moment, creating a record for a specific purpose, and once that purpose was complete, the record could be thrown out, placed in a file, deleted (as in an electronic document or email), or just shoved in a drawer. The amount of lost history from not preserving the day-to-day documentation of business is incalculable.

There were people who did recognize the value of those records. Librarians, secretaries, history professors, and administrators have preserved records over the years, sometimes because they recognized their value, or because they wanted to preserve their 
own, or someone else's, legacy. Motivation was irrelevant in the long run; it was the preservation of the records that was important. The creation of university archives gave a home to those preserved records. While the environmental conditions were many times far from perfect, as seen in Illinois State University's (ISU) Williams Hall, the archives provided a central location for important historical and legal records. Yet, there was resistance. Departments, offices, and people hung onto their records, or destroyed records that appeared to be past their usefulness without regard to their possible value. Professors tossed their syllabi, and did not give a thought to depositing copies of their articles and research written and conducted while employees of the university into the archives. What was needed was an active records management program to educate departments regarding the appropriate disposition of inactive records.

What exactly encompasses a records management program? Does that mean that all records are kept in perpetuity? What about records containing confidential information; will that information remain confidential? What kind of records are saved? What constitutes a record? Why is a records management program necessary? How does a records management program relate to the archives? Those would be typical questions asked when the concept of a records management program is introduced.

A records management program is concerned with these records through their life cycle - from their birth, through their useful lifespan, and when they are obsolete. As part of a records management program, a retention schedule determines which records have continuing historical or legal value and should be retained, how long the records must be retained, and their disposition, i.e. are the records to be destroyed or should they be sent to the archives. Following a records management program ensures that there are 
"no gaps in the information which should be filed," allowing for an administrative history of a college, unit, department, or office, as well as efficient access to non-current records as necessary. ${ }^{1}$

All the universities examined have some kind of records and information management program (RIM). The State of Illinois notified the state universities in 1983 that the State Records Act (5 ILCS 160/1) applied to universities as well as other state agencies. ${ }^{2}$ This act required that state agencies, not dispose of any records in violation of the act, as the records are the property of the State of Illinois and are to be "to be available for the use, benefit, and information of the citizens." 3 The records were to be made and preserved "containing adequate and proper documentation of the organization, functions, policies, decisions, procedures, and essential transactions of the agency ${ }^{4}$ The agency, in this case the universities, "shall provide for effective controls over the creation, maintenance, and use of records in the conduct of current business." The universities are required to appoint a records officer who will apply "standards, procedures, and techniques to improve the management of records, promote the maintenance and security of records deemed appropriate for preservation, and facilitate the segregation and disposal of records of temporary value," and "shall provide for compliance" with the statute. 5 This law also applies to electronic and "born digital" records.

\footnotetext{
${ }^{1}$ Margaret Cross Norton, "Services and Resources of an Archives," in Norton on Archives: The Writings of Margaret Cross Norton on Archival and Records Management, ed. Thornton W. Mitchell (Carbondale: Southern Illinois University Press, 1975), 73.

2 “Administration and Consulting," Southern Illinois University Records Management, accessed April 30, 2015, http://recordsmgmt.siu.edu/administration-and-consulting/index.html.

${ }^{3}$ State Records Act, Illinois Compiled Statutes, ch. 5, no. 160, sec. 1.5 (2003), accessed May 4, 2015, http://www.ilga.gov/legislation/ilcs/ilcs3.asp?ActID=86\&ChapterID=2.

${ }^{4}$ State Records Act, Illinois Compiled Statutes, ch. 5, no. 160, sec. 9 (2003), accessed May 4, 2015, http://www.ilga.gov/legislation/ilcs/ilcs3.asp?ActID=86\&ChapterID=2.

${ }^{5}$ Ibid.
} 
While the universities had established their archives as repositories for their records, there were no policies in place besides instructions to check with the archivist prior to destroying records. This statute made unauthorized destruction of records a Class 4 felony punishable by up to three years in prison. This spurred the universities to establish record retention schedules so staff would know how long to keep records and when the records could be archived, disposed of, or destroyed. The term "disposed of" is vague, maybe purposefully so. It leaves it open whether the records are to be destroyed or turned over to the archives. For example, in ISU's records retention program, under the heading Administrative Correspondence, the policy states that correspondence should be kept in the office for three years. Then, it can be disposed of, with confidential material being shredded or destroyed in some other secure manner. So, the term disposed of gives some leeway for the archivist to go through the papers, retaining the correspondence of historical, fiscal, or legal value. When Anderson retrieved records from the Dean's Office in the College of Arts and Sciences, a staff member had to sign a form giving the records to the archives and stating that any unwanted material should be returned to the office or destroyed by the archivist. Most university archives do not retain confidential records like personnel files, faculty evaluations, or student grades due to privacy issues. However, U of I, SIU, and EIU have some grades and evaluations within various collections. ISU does not have any collections listed containing grades, but some collections do contain program, course, faculty, and chair evaluations.

Southern Illinois University established its records retention program in $1990{ }^{6}$ ISU began crafting its records retention program to bring itself into compliance with state law in 2006, and had an approved program by 2007. The University of Illinois

\footnotetext{
6 “Administration and Consulting," Southern Illinois University Records Management.
} 
established a task force in February 2010 to develop a policy, which the U of I delivered in December, 2010. The records manager at Eastern Illinois University did not know exactly when the program began there, but she stated that it was soon after the state required it. ${ }^{7}$

The development of the programs is not the focus of this chapter, but rather the condition of each program. According to the National Archives and Records Administration (NARA), an effective RIM program requires senior management support; a clear definition of program objectives, responsibilities, and authority; allocation of sufficient resources to administer the program; assignment of the program to an appropriate office within the agency's organizational structure; continuous training for records and information management staff; and regular interval evaluations to monitor compliance and program effectiveness."

SIU's record management program is a department in the university's library, under the direction of Michael Reiman. The program's mission is to "provide a sound records management program to ensure the University retains the necessary information to meet legal, financial, administrative, research, and historical needs set forth in the State Records Act, for the orderly gathering and processing of University information in the most cost-effective manner."

A records management program also works in conjunction with the archives to "maintain a vital records protection program" $" 10$ through a retention schedule. For

\footnotetext{
${ }_{8}^{7}$ Cathy Kimball, interview by author, Charleston, IL, March 9, 2015.

8 "Records and Information Management Self-Evaluation Guide," National Archives and Records Administration, accessed May 4, 2015, http://www.archives.gov/records-mgmt/publications/records-andinformation-management-self-evaluation-guide.pdf.

9 "Welcome to Records Management," Southern Illinois University Records Management, accessed May 5, 2015, http://recordsmgmt.siu.edu/.

10 “Administration and Consulting," Southern Illinois University Records Management.
} 
example: Val is the secretary for the College Council and is responsible for taking notes, then creating the meeting minutes for each meeting. The creation of the meeting minutes would be the birth of the record. Val then distributes the minutes to the council members, posts them to the college website, and files the minutes in a folder for the 2014-2015 year. The minutes for that year remain in Val's filing cabinet for five years as per ISU's retention schedule. This represents the use and maintenance of the record's life cycle. Every summer, Val goes through her files, while referring to the retention schedule to see what can be removed and sent to the archives or shredded. In the summer of 2020, she removes the file of meeting minutes from 2014-2015 and arranges to send it to the archives for permanent retention, as per ISU's retention schedule. This part is the disposition of the record's life cycle. An active records management program ensures that records that should be retained in the university archives actually make it there in a timely manner.

In SIU's retention schedule there are ten units, with various departments listed within that unit. The person charged with maintaining the office/department records has to know to which unit the office/department reports. For example, if Susan works in the History department and is ready to dispose of/archive records, she would find History's retention schedule within the Provost and Vice Chancellor unit. Each department is responsible for its own records and for following the retention schedule that applies to that department, but it is not mandatory for departments to dispose of or archive records once their retention period has passed. Some departments do opt to hold onto their records past their retention dates should staff have a need to reference them. An audit 
completed last year placed the estimated compliance rate at 70 percent. ${ }^{11}$ It also revealed that the university's administrative side was proactive in following the retention schedules, while the academic side was weak. Since the audit, Reiman states that the academic side has been contacting the department for consultation services. ${ }^{12}$

With so much business and correspondence being conducted via email, the archival profession is in the midst of determining how best to preserve and store electronic records. In the meantime, SIU has forged its own policy regarding electronic records. Electronic record retention is addressed in the Records Management Policy Manual, available on the Records Management webpage. The Records Management Department also provides guidance regarding email, having readily available information from the Office of the Secretary of State regarding the state's policy on what must be retained and where it should be stored.

Besides providing consultation services, the Records Management Department has a number of resources available on its website to provide guidance and instruction for those responsible for departmental records. Checklists are provided for preparing records for filming and imaging. Specific instructions regarding preparation of records for disposal are provided, from the removal of staples to the size of the boxes accepted. Of course, should staff have any questions, contact phone numbers and emails are also provided.

EIU's records management program is a department under the vice president for business affairs. As the custodian of records, Cathy Kimball has the responsibility for administering the program. The position was full-time from 1986 to 2001, until the first

\footnotetext{
${ }^{11}$ Michael Reiman, interview by author, email, May 1, 2015.

${ }^{12}$ Ibid.
} 
custodian retired. The position then became part-time until Kimball assumed the position in 2014, when it became full-time again. When she began, the record storage area was not well organized. Kimball reorganized the area and used a barcode system to identify boxes by department.

Kimball's goals for the department are threefold: policy, training, and enforcement. ${ }^{13}$ Her supervisor changed enforcement to encouragement, since disposing of or archiving records that are past their retention period is not mandatory. To encourage departments to consistently follow their retention schedules, Kimball provides training to the departmental staff responsible for records - the Departmental Records Coordinator (DRC) - and has a presentation for new employees during new employee orientation. $^{14}$

EIU's Records and Information Management homepage provides users with the definition of a record, as well as what constitutes a record with historical, archival, or research value. Links are provided for other definitions, and to a webpage that describes what RIM is and why it is important. It also states that "Each employee has an important role to play in protecting the future of the organization by creating, using, retrieving, and disposing of records in accordance with the organization's established policies and procedures." 15 The webpage includes instructions on how to manage email, how to name and organize files, training materials for DRCs, retention schedules, instructions regarding how to retrieve records, how to archive records, and best practices.

Regardless of whether the records are to be disposed of or archived, a fully

\footnotetext{
${ }^{13}$ Kimball, interview.

14 Ibid.

15 "What is Records and Information Management," Eastern Illinois University Records and Information Management, accessed May 1, 2015, http://www.eiu.edu/recordsmanagement/what.php.
} 
completed form must accompany the box. All forms are available on the RIM website under the specific topic, i.e. "Record Disposal Request." Instructions for completing the form are available by clicking the "Records Disposal Request" tab on the left side of homepage. The rest of the process is explained, including what to include in the email that must be sent to the EIU Records Manager.

At $\mathrm{U}$ of $\mathrm{I}$, the records and information management services (RIMS) unit is located under the chief information officer, who reports to the vice president for academic affairs. The university created a task force in 2010 that would

recommend a structure to deliver a set of services across the University that [would] support the development and maintenance of policies related to the management of data records and information resources created or received in the course of transacting the business functions of the University; provide assistance related to the management of these data, records, and information resources; [and] ensure the capture, preservation, and future accessibility of data, records, and information resources of enduring value. ${ }^{16}$

That task force recognized that an archivist alone would not be able to devote the amount of time necessary to oversee an active records management program, and that "such a program would...help to protect vital University records, limit legal liability, support the preservation of historic records, promote scholarship and teaching excellence, improve operational efficiencies, and increase efficiency in responding to requests for information."17 The task force recommended the creation of a RIMS program placed under a top-level university executive that would work with the archivist and other experts "to create and sustain shared services and a collaborative working environment regarding records..."18

\footnotetext{
16 "Final Report," Records and Information Management Services (RIMS) Task Force, University of Illinois, Champaign-Urbana, accessed May 11, 2015, https://uofi.app.box.com/s/q96pqv6acgw0ri8fmz5y.

${ }^{17}$ Ibid.

${ }^{18}$ Ibid.
} 
Joanne Kaczmarek is the director of the program at the main campus in Champaign-Urbana. Other U of I campuses will not be discussed in this examination. Kaczmarek has a staff that includes a coordinator, three assistant directors, and a business and information management specialist. Its purpose is to "provide a cohesive approach to the effective management of records and information resources throughout the University of Illinois, across all departments and campuses."19 The department's objectives include protecting vital $\mathrm{U}$ of I records by establishing records management plans for departments and developing methods for "trustworthy and efficient purging of information resources", ${ }^{20}$ improving operational efficiencies by reducing duplication, streamlining existing systems, and aligning $U$ of I's business practices with state laws and regulations; and promoting scholarship and teaching excellence through preserving historic records, standardizing policy development, and increasing "opportunities for collegial collaboration around data management." ${ }^{21}$

According to Kaczmarek, while it is desirable for units to consistently follow their retention schedules, it is not mandatory. ${ }^{22}$ To encourage compliance, the RIMS team provides training for units, as well as self-paced training modules available from their webpage. Through their webpage, they provide a guide for records and information management, policies regarding the preservation of electronic records and email, information on scanning records, record retention schedules, storing inactive records, how to transfer records to the archives, as well as decision trees to aid in scanning, defining a record and the record disposal process. A comprehensive FAQ section covers

\footnotetext{
19 "Records and Information Management Services," University of Illinois, accessed May 11, 2015, https://www.uillinois.edu/cio/services/rims/.

20 "About RIMS," University of Illinois, accessed May 11, 2015, https://www.uillinois.edu/cio/services/rims/about_rims/.

${ }^{21}$ Ibid.

${ }^{22}$ Joanne Kaczmarek, interview by author, email, May 1, 2015.
} 
the most commonly asked questions and other questions related to records management.

Illinois State University's Records Management program is housed under the provost's office. Assistant Vice President for Academic Administration Salvatore Catanzaro - the university records Officer - is "designated as the individual to whom offices submit their Disposal Forms for signature before submission to the State Records Commission." 23 No department for records management exists at ISU, so units manage their own records. The administration believes that "keeping the management of records decentralized minimizes administrative costs."24

The homepage of the records management program consists of tabs at the top for the President's Office, Academic Affairs, University Advancement, Student Affairs, Finance and Planning, Records Disposal Certificates, and Forms. The text explains the Illinois State Records Act and the university's process to become compliant with the act. A link is provided for staff to learn how to use the site "to determine what to do with a record., 25

Clicking on the link opens a Microsoft Word document titled, "How to Use this Website to determine what to do with a Specific Record." The first step instructs the user to locate the document in the "Applications" section of the website. Going back to the website, there is not an "Applications" tab. Where do I go to find "Applications?" In clicking the tabs, I found an "Application Cover Page" in Word and as a PDF, which was not what I was looking for as it was an application for records disposal. I decided to begin clicking the tabs to find "University-Wide Documents," which I did locate under

\footnotetext{
${ }^{23}$ Salvatore Catanzaro, interview by author, email, May 14, 2015.

24 Ibid.

25 “Records Management," Illinois State University, accessed May 4, 2015, http://recordsmanagement.illinoisstate.edu/.
} 
the president's office tab. I was able to follow the instructions fairly easily and as I went through them, I noticed a note that stated that University-Wide Documents were located in the President's Office. ${ }^{26}$ The document also states, in bold letters, "You are not REQUIRED to dispose of records if the retention period has passed. You are PERMITTED to dispose of them, according to the terms of the application and disposal certificate. ${ }^{, 27}$ It does caution that the university archivist should be consulted if there is any doubt about whether a record should be sent to the university archives. Beyond the contact information related in the instructional document, no other support or instructions are provided on the webpage.

Since the State Records Act makes the unauthorized disposal of records a felony, the four universities examined emphasize the legal disposal of non-current records. To aid users, SIU, EIU, and U of I provide varying degrees of support and instruction regarding record management, retention schedules, storage, and legal disposal. These three also provide useful tools such as a definition for what constitutes a record, FAQs, manuals and guides, new employee training, departmental training, and consultation services to aid in efficient filing. The ISU records management program does not offer any support beyond phone numbers and email addresses of the records officer and his office support person. SIU, EIU, and U of I also have active electronic records management systems to store and preserve emails, electronic records, and born-digital records. These systems are still works in progress, but they are working to bring the systems into compliance with the Government Electronic Records Act passed in 2010. ISU's Records Retention policy makes no mention of electronic records, yet state law is

\footnotetext{
26 "How to Use this Website to determine what to do with a Specific Record," Illinois State University, accessed May 4, 2015, http://recordsmanagement.illinoisstate.edu/.

${ }^{27}$ Ibid.
} 
very specific regarding retention schedules, databases, file formats for permanent retention, storage media, access, backup copies, and how the records are identified. I believe that if the state were to audit the university's compliance with this law, the university would be found non-compliant.

For example, according to law, electronic records are considered the same as nonelectronic records and should follow the same retention schedules. According to ISU's retention schedule, faculty evaluations are to be retained in the office for five years. This includes the Department Chair evaluations. In the College of Arts and Sciences, this evaluation is created online and the results are maintained in a survey platform, i.e. SelectSurvey, SurveyMonkey, etc. Since the ballot and results constitute a "born digital" record, both the ballot and the results should be treated as if they were hard copy and held for five years, and, after seeking and receiving permission from the State Records Commission, should be destroyed. The office has maintained those records in the survey platform, but only because office staff had previous knowledge of the records management program. If that had not been the case, staff may have seen no reason to keep past results and may have deleted them, which, according to Illinois law, is a felony. Yet, if there is no information provided to new employees in an office manual or in an orientation, how are they to be aware that there is a records management program?

There is a plan in the works through ISU's LEAPForward initiative, which began in 2013. ISU is also the only one of the universities examined that specifically informs users that they are not required to dispose of records. While the disposal of non-current records is not required by state law, Robert Chayse Boots, archival program director for the Illinois State Archives, stated that "from a risk management perspective, it is 
recommended that agencies dispose of their records as soon as their life-cycle has been met, and an approved Disposal Certificate has been provided through this office."28 SIU, EIU, and U of I records management programs actively encourage departments to follow the retention schedule through support and training. ISU's records management program does nothing to encourage departments to follow the retention schedule.

Why be concerned with the disposal of non-current records? First, disposing of the appropriate records saves money and space. As records accumulate in an office, file cabinets become full, requiring the purchase of more filing cabinets. The more filing cabinets an office has, the less space it has. Eventually, the office would be forced to move the overflowing cabinets to another space, possibly a nearby room. In a university, classroom and office space is normally at a premium. To use a room to store records that would otherwise be destroyed is wasting limited resources.

Second, disposal of non-current records is more efficient. If a Freedom of Information Act (FOIA) request came through, wading through years and years, and files and files of unimportant records to find that one record, even in the most organized filing system, would be a daunting task. Being able to quickly and efficiently pull the pertinent record for the FOIA request would please the General Counsel or whichever office handles those requests and save the university from a lawsuit. If the archives received a FOIA request for a record that should have been in the archives, but was not, that request would have to be routed to the appropriate office, and that office had better have that information, or be in violation of state law.

Third, disposal of non-current records protects vital information. Student records, personnel files, student disciplinary records, as well as other records contain confidential

\footnotetext{
${ }^{28}$ Robert Chayse Boots, interview by author, email, May 14, 2015.
} 
information that cannot be released without permission, if at all. Departments would not want to permanently store these records in their space, and they cannot be haphazardly dumped into a trash can after their lifecycle is complete, nor can the archives take them because of privacy issues. A good records management program indicates how the records are to be disposed of, usually by shredding.

While the retention schedules guide departments and offices through the disposal process, they also guide them in what should be preserved permanently by maintaining the records in the department indefinitely, transferring the records to the archives, or sometimes both. While the reasons for preserving records may seem straight forward, office staff may not think beyond the record's current use.

Of course, records have historical value. For a university, records preserve institutional memory. The letters of past presidents, the scorebooks, shot charts, and programs from ISU's basketball, football and baseball teams coached by Joseph T. Cogdal from 1927 through 1965, student election results, and syllabi from professors all add to institutional memory.

Besides historical value, records have legal, fiscal, and evidential value. A FOIA request for a record that had been destroyed when it should have been preserved would most certainly be costly to the university. Personnel files, budget files, search files for open positions, disciplinary files, contracts, and other such records are important to have readily available for a period of time should accusations of wrongdoing arise. These files documenting procedures and agreements are valuable evidence in an investigation or lawsuit.

Why are offices and departments not disposing or archiving their records? Lack 
of personnel is the main reason Michael Reiman hears from SIU's departments. ${ }^{29}$ At EIU, Cathy Kimball hears that the departments "need the information." 30 She acknowledges that may be true, but questions how much records that are five or six years old or older are needed. Some departments want to keep them forever. ${ }^{31}$ She, like Reiman, also hears that there just are not enough staff to do the job. But, records with long-term value can be sent to the State Records Center and can be retrieved with twentyfour hour notice. ${ }^{32}$ While the task is daunting at first when viewing file cabinets full of years' worth of records, once the initial task of organizing, boxing and labeling files past their retention date has been completed, a time-consuming endeavor in the first year, the task need only be performed once per year after that. SIU, EIU and U of I all provide guidance, training, and consultation in organizing and maintaining filing structures to aid the process.

Why is the records management program at ISU not promoted? I am able to speak from experience regarding the lack of promotion of the program at ISU. When I first started at ISU in 2007, no mention was made of any record management program in my orientation. My office, Community Rights and Responsibilities - the student conduct office - kept paper files on all students and organizations with disciplinary records. There were six five-drawer lateral file cabinets, 67 inches tall and 42 inches wide, full of files. We were running out of space and needed to either get rid of records or obtain more file cabinets. The coordinator mentioned that we could dispose of some of the records - the ones that were seven years old or older - once we had permission from the associate dean.

\footnotetext{
${ }^{29}$ Reiman, interview.

${ }^{30}$ Kimball, interview.

${ }^{31}$ Ibid.

32 "Records Management Reference Manual for Illinois State Government Agencies, 2014," Illinois Secretary of State, Illinois Archives, Records Management Division, 8.
} 
We eventually received permission to dispose of records that were seven or more years old, except for suspension and dismissal records, which were kept indefinitely. A few more years went by, and we were once again facing a space shortage. By that time, I had stumbled across the University Archives while investigating what I could do with Student Government records, so I began searching for some sort of direction as to what to do with university records. That's when I came across ISU's records management program and the retention schedule. I found out that we were keeping discipline files two years too long. While for some records, that may not matter; for discipline records, it could make the difference of a student getting hired, as the FBI, CIA, and other agencies frequently asked for disciplinary histories. We were disclosing information that should have been destroyed, according to the retention schedule. If I had not searched for this information, I never would have been aware that ISU had a records management program and the office would have continued to release student conduct information that should have been destroyed. I left the office shortly after that discovery, and the error has since been corrected. If the records management program had been promoted and adhered to, this would not have happened.

The question remains, why has the state not made following the retention schedules mandatory for state agencies? 


\section{CHAPTER V}

\section{COMPARISON OF THE UNIVERSITIES}

According to the Society of American Archivists (SAA), "an effective archival program requires a mandate from the president or governing board that authorizes the archivist to identify records of enduring value, document their physical location, preserve them, and establish methods of control that provide ready and consistent access to archival holdings." ${ }^{1}$ For all four of the archives, those holdings include not only university records, but also records of local, regional, and state significance that have been donated to and accepted by the university archives, although April Anderson is trying to find new homes for the collections that fall outside of the scope of university records. To meet these measures, an archive must have resources such as professional and support staff, facilities to house the collections in a safe and secure environment, an adequate budget for personnel, supplies, and equipment, and also a "technologically current environment."2

The ISU archives was officially founded by President Samuel E. Braden on March 31, 1970 as a repository for official university records. The archivist position was a part-time position until Anderson, ISU's first full-time archivist, started in 2011. ISU archives also employs a full-time archivist assistant who does much of the processing. There is also a part-time position for a

\footnotetext{
1 "Guidelines for College and University Archives," Society of American Archivists, accessed May 21, 2015, http://www2.archivists.org/node/14801.

2 Ibid.
} 
graduate student, and plenty of projects for interns and volunteers.

For Southern Illinois University and Eastern Illinois University, it is unclear whether their archives were established from a presidential mandate. Neither archive had much information pertaining to the history of their respective archives. It appears likely that SIU's archives did at some point receive authority from its president or board of trustees since its stated mission is the preservation of "the academic, athletic and administrative legacy of the university from 1874 to the present." ${ }^{\prime 1}$ EIU seems to have developed from the need to organize information for the university's centennial, even though there had been an archivist prior to that time. Whether its president ever mandated its existence as a repository for its records is unknown. Both archives had part-time archivists who had other library or special collection duties outside of archives. SIU's archivist position became full-time in 2005, and included teaching duties, which is not uncommon. EIU's archivist position remains part-time. EIU and SIU have no other full-time staff for their archives. Both universities have graduate student help, but EIU's graduate students are not able to process collections, due to the small amount of time the interim archivist is in the archives to provide supervision. On occasion, there are classes that take on a processing project for EIU's archives.

U of I's archives were formally established in 1963. U of I had a full-time professional archivist - as opposed to a librarian - in 1963, before the majority of colleges and universities had even established archives. Only 9 percent of colleges and universities in the United States and Canada employed professional archivists in $1966,{ }^{2}$ making their archival development at that time atypical. U of I has an assistant archivist,

\footnotetext{
1 “University Archives Collection,” Morris Library, Southern Illinois University, accessed May 21, 2015, http://www.lib.siu.edu/university-archives

${ }^{2}$ Warner, "The Status of College and University Archives," 235.
} 
an electronic records archivist, a reference archivist, an archival reference and operations specialist, as well as two visiting archival reference and operations specialists. Again, U of I is atypical of colleges and universities, as less than one-third of college and university archives had more than one full-time professional, according to a 1980 survey of college and university archives. ${ }^{3}$

Safeguarding records from theft, damage, and destruction is a primary concern for archivists. That is why security in an archives is an essential component of archival management. Security includes such things as proper storage of records, protection from fire, water, insects, and rodents, proper environmental conditions, and of course, theft. But archivists have to balance record safety and security with public access. The SAA has set standards for archival facilities. The standards provide guidance on fire protection, security, materials and finishes, lighting, functional spaces, and equipment, as well as for site evaluation and construction. ${ }^{4}$ The conditions found currently in each archives will be summarized and compared to the standards set by the SAA. The standards are in the midst of revisions, but most of the information has not changed. If the information is in the revision process, it will be noted.

Like many institutional archives, all the university archives examined were first housed in spare spaces in university library basements, barely adapted to suit their function. It was not uncommon for water and heating pipes to run through these spaces, leaking and damaging records. Environmental controls were the same as those for the library, with little to no ability to control temperature and humidity levels apart from the

\footnotetext{
${ }^{3}$ Nicholas C. Burckel and Frank Cook, "A Profile of College and University Archives in the United States," American Archivist 45, no 4 (October 1982): 415.

4 "Archival and Special Collections Facilities: Guidelines for Archivists, Librarians, Architects, and Engineers," Society of American Archivists, accessed May 21, 2015, http://www2.archivists.org/category/standards-type/guidelines.
} 
library conditions. Security beyond controlling stack access depended largely upon security within the library.

Since that time, the ISU archives moved from its former location on campus in what is now Williams Hall to its current location on Warehouse Road in 2008. The facility, while superior to the former location, is not the ideal location. The warehouse is built on a slab that has sunk over the years, making conditions right for water to seep in under the doors due to poor drainage. The SAA guidelines state that "all walls, ceilings, and floors of stacks must be constructed of masonry" to ensure the best fire protection. ${ }^{5}$ The building housing the archives is a metal warehouse. The floors are concrete, but the walls are of corrugated metal and one section of the interior wall is a conventional wall with wooden studs and particle board. Ceiling-mounted water sprinklers provide fire suppression. The facility has been home to mice and other rodents, a condition which is constantly monitored by staff. As for environmental controls, humidity sensors are placed among the stacks and read on a daily basis. However, to control temperature and humidity, facilities must be called, and even they are limited in their ability to keep levels within acceptable ranges.

Security at the ISU archives is adequate. The building itself is locked at 4:00 p.m., and security patrols periodically throughout the night. The archives area is separate from the rest of the warehouse and offices, and is locked, with only three people having a key. Maintenance and cleaning staff must request access. The records area in the archives is surrounded by tall wire fencing and access is gained through either a padlocked gate or a locked doorway set into the fencing. There is also a security camera in the stack area. The overhead doors, which give access to the archives' side of the

\footnotetext{
${ }^{5}$ Ibid., 22.
} 
building, are secured with sensors and padlocks. There are no windows in the archives area. While only staff have access to the stacks and must bring requested records to the reading room, the reading room itself is isolated from view of staff. SAA guidelines state that the reading room should be "designed to provide clear supervision of all researchers by archives staff and/or monitors and contain as few visual barriers as possible." ${ }^{6}$ Since the arrangement does not allow this, security cameras are installed in the reading room, feeding to Milner Library. Sensors and motion detectors are on the rolling overhead doors. Handles have also been removed from emergency exit doors and replaced with inside crash bars to prevent the ability to pry those doors open with a crow bar. The building also has two separate alarm systems, one for the warehouse and one for the archive offices.

ISU is not alone in having an archival repository that does not meet SAA recommendations. EIU's archival facility is the least acceptable for meeting recommended environmental conditions. Water pipes run through the archives, increasing the odds of water damage to the collections. There is also no fire suppression system in the archives, nor are there smoke alarms within the vault itself. "If the library goes, the archives are going with it," stated interim archivist Bill Schultz. ${ }^{7}$ There are humidity sensors located on the shelving throughout the vault, and temperature and humidity can be adjusted by facilities staff. The floor is concrete, but with a wooden platform down the middle aisle. Wood and wood composites are not recommended flooring material as wood can attract pests such as termites, and can also emit "volatile

\footnotetext{
${ }^{6}$ Ibid., 39.

${ }^{7}$ Schultz, interview.
} 
acids" and formaldehyde, which will oxidize to form formic acid. ${ }^{8}$

Since EIU's archives is located within the library, security staff are present, providing adequate security. The doors to the archives department are locked, as is the vault. There are no windows in the basement facility, further enhancing security. However, the door to the department is constructed of glass and wood, and there are boxes of unprocessed records unsecured in the hallway and other accessible rooms. The records in these areas, some stored in cardboard boxes, are not subject to the same environmental controls as those in the vault. The small reading area is clearly visible to staff, and access to the vault is limited to the archivist.

SIU's facilities are newer, with renovations completed in 2009. The floors are concrete in the basement and in the second floor stacks, but linoleum in the first floor stacks, a material not recommended for use in an archives since it is "often finished with polyurethane and is installed using adhesives," ${ }^{9}$ emitting gases that are damaging to holdings. The ceilings are concrete, but the walls in all the stacks are drywall with wood framing, something the SAA discourages due to flammability.

SIU has surveillance cameras in the reading room and at the entrance to the department. There are also a series of locked doors that are designed to prevent access to the area after operating hours. To access the department, a visitor must enter through the Hall of Presidents and Chancellors. That door locks automatically at 4:30 p.m. Then, the door to enter the department also locks automatically at 4:30 p.m., and only those with a key fob can gain access after that time. The first floor stacks can only be accessed through a locked door in the processing room, which also is locked. An elevator is the

\footnotetext{
8 "Archival and Special Collections Facilities: Guidelines for Archivists, Librarians, Architects, and Engineers." 104.

${ }^{9}$ Ibid.,106.
} 
only access to the second floor stacks and the basement stacks. The elevator, which must be operated with an access fob, is also in the processing room. The processing room is the most vulnerable of the rooms, as it faces an exterior wall and is lined with large windows. However, if an intruder were to gain entry to the processing room, there would be no easy access to the stacks.

U of I's main archives and visitor space were upgraded in May 2015. New stationary shelving holds the most used collections. The floor in the new space is linoleum, which is not recommended. The walls are drywall, with interior walls having wooden studs. Office furniture and equipment are housed in the same area, which the SAA advises against due to the furniture's combustibility and the equipment's potential for igniting a fire. The archives' original basement location where much of the collection will remain is better in some ways and worse in others. The floor, ceiling, and walls are concrete. However, water pipes run through the area and tend to leak. When I visited the archives, plastic sheeting was draped over some of the stacks to prevent damage from leaking pipes. Being on the basement level, they every once in a while have water seepage, but since the stacks are a few inches off the floor, the water does not pose a threat. Environmental controls, on the other hand, were nearly impossible to manage. The space opened into the reading area, with no doorways. The reading area had to be kept at a comfortable temperature for patrons, which was not the best for the collections. Humidity levels were also difficult to keep within acceptable levels, even with the sensor data. Facilities could make adjustments, but as with the other archives, they could do little to keep both temperature and humidity stable.

The Student Life and Culture Archives (SLC), while in a space not specifically 
designed for archives, has one of the best facilities. The archives vaults are all concrete walls, floor, and ceiling. Since they were originally built to store apples, the vaults remain cool throughout the seasons. Even so, the building had to be retrofitted to provide adequate temperature and humidity control. Humidity sensors are placed throughout the stacks and are read on a daily basis. Water has not been an issue in the vaults and no pipes run through the vaults. However, this means that there was not a fire suppression system within the vaults. That will soon be rectified by a $\$ 1.1$ million grant to upgrade the environmental system and install a fire suppression system in the vaults.

Security at the main $\mathrm{U}$ of I archives is similar to the other archives examined, with locked doors, limited access, and security patrols. Other security measures are in place, but, at the request of archivist William Maher, the specifics of U of I's archival security will not be discussed. At the SLC security of the records is "an issue," according to Ellen Swain. ${ }^{10}$ The building is shared with Public Archeology, Facilities and Service, and the Sousa Archives, meaning that there are four different groups who must have access to the building. Facilities opens the building at 7 a.m. and is supposed to lock it up between 5:15 p.m. and 6:00 p.m. However, Swain has had to call Facilities to come lock the building on some days, as it had been 8:00 p.m. and it had not been locked yet. All archives spaces are locked, including offices, storage rooms, work rooms, and the like, and remain locked throughout the day until staff need access. ${ }^{11}$ Archives staff have access to the keys during the day, but the keys are locked up at night in a secure location. Four archivists have a key to access the key box, and three have a key to the building. Spare keys are locked away in an undisclosed location. The library keeps a record of all

\footnotetext{
${ }^{10}$ Swain, interview.

11 Ibid.
} 
employees who have keys assigned to them. The area is patrolled by University Police, and may be more heavily patrolled than other archives, as SLC is next to the President's house and to student housing. The budget issue raised its head in SLC's attempt to make the archives more secure. After a break-in in 2012, Swain and administrators investigated getting an alarm system. Lack of funds prevented the purchase and installation of a system.

Funding has historically been a problem for many university archives. Of course, an adequate budget varies according to need - what may be adequate for the university archives at EIU may not be adequate for U of I. ISU's archives does not have its own budget line, nor do any of the other universities examined. The budgets are part of the overall library budget, so rather than Anderson receiving, for example, $\$ 100,000$ to spend throughout the year, she has to stand in line at the trough in the hope of being able to receive monies for need-based extras such as mobile shelving. This is not unusual for institutional archives to have their budgets subsumed into their parent unit. According to a 1985 archival institution census, only 42 percent of all academic archives surveyed reported that they had separate budgets. ${ }^{12}$

Funding for these university archives can be tied to the size of the university and the age of the archives. $\mathrm{U}$ of I is the largest university examined, having over 44,000 students, and has the oldest established archives. They also have had a full-time archivist longer than any of the other universities. Their active records management program funnels non-current records, both paper and electronic, to the archives to document the administrative and cultural history of departments, colleges, registered student

\footnotetext{
${ }^{12}$ Paul Conway, "Perspectives on Archival Resources: The 1985 Census of Archival Institutions," American Archivist 50, no. 2 (Spring 1987): 180.
} 
organizations, athletics, and alumni.

ISU, having a total enrollment of just over 20,200 students, and an archive officially founded in 1970, finally realized the value of its archives in 2011 when the university hired a full-time professional archivist. The library administration found funds to not only hire a full-time archivist, but also an archivist assistant, recognizing that the job entailed not just processing but also outreach. Having an assistant freed Anderson to be able to conduct outreach activities. However, while the university values its "fun" history - old photographs and memorabilia - its records management program, or lack thereof, indicates that university administration believe saving administrative costs is more important than preserving administrative history. But how much is truly being saved? Rather than being able to build the archival holdings by focusing her outreach on alumni, and former faculty and staff, Anderson must spend much of her outreach time gathering records that should already be going to the archives regularly through the records management program.

SIU, while a bit smaller than ISU, with an enrollment of nearly 18,000 students, hired a professional archivist in 1965, five years prior to ISU, but only two years after U of I. While the archival duties at SIU were only a portion of the position, the position was filled with a professional archivist, not a librarian or a rare books specialist or a history professor. This put the archives ahead of ISU developmentally, so when the archivist position at SIU became full-time, that archivist did not have to go back and reprocess collections. Their archives also contains records from a wider array of departments than ISU due to its active records management program, and the collection of electronic records for the archives can also be attributed to its records management 
program.

The only archive that would qualify as substantially underfunded is EIU, which is the smallest of the universities examined with just under 8,900 students. It is evident that the archives does not receive an adequate amount of funding, given that the previous archivist was only part-time, and interim archivist Schultz is quarter-time. Schultz was not sure how long he would serve as interim archivist and had doubts as to whether EIU would even hire a new archivist. While their records management program, faculty, and staff send records to the archives, there is no one to process them and make those records available for research. The Keep, EIU's online institutional repository, receives more support than the EIU's archives, and with more staff and modern equipment, is better funded.

Technology-wise, ISU archives lags behind both U of I and SIU archives, which have the ability to receive and preserve electronic records as well as paper records. In the area of electronic records, ISU also lags behind EIU. While EIU's records management program collects electronic records, that ability has not filtered down to the archives due to the inadequate funding and staffing of the archives. If EIU ever does put more money into its archive, the electronic records will be there, should the university choose to house them there. However, with funding, staff, and technology already in place, it seems more likely that The Keep will house the electronic records. As of now, ISU does not have a program in place for the collection or preservation of electronic records, but a plan is in the works and should be up and running by December 2015.

Comparing the four archives to the SAA standards for an adequate archives, all the archives examined fall short in one way or another. That being said, both U of I and 
SIU come the closest to that ideal, while ISU lags behind in the technology area. EIU's archives, both the traditional archives and The Keep, do not come anywhere near being an adequate archive in any of the categories listed by the SAA.

Moving on now from what physically makes an adequate archive to archival processes, I will explore various processing theories and if and how each archivist uses those theories in processing the collections. I will then examine how the archivists utilize various forms of outreach to engage users and promote their respective holdings.

There are multiple ways collections can be processed, each with its own advantages and disadvantages. No one way is the correct way, but there are minimum standards for processing a collection - respect des fonds, provenance, and original order. Respect des fonds refers to the individual, family, or organization that created the records, while provenance refers to the history of ownership of the items or records. Basically, records from the university president's office will remain separate from records from a vice president's office, and so on, even if some of the records are regarding the same topic. Original order is the arrangement of records that has been established by the creator. This does not mean that if the archivist receives a file crammed full of correspondence from the Dean of the College of Arts and Sciences that the correspondence has to remain in that same order. It does mean that that file of correspondence stays intact, with the contents having been arranged in a logical order, if the archivist so chooses. As the SAA states, "The principle of respect for original order does not extend to respect for original chaos. ${ }^{, 13}$ Both ISU archivist Anderson and SIU archivist Gorzalski will rearrange records to bring order to records if there is none.

\footnotetext{
13 "Glossary," Society of American Archivists, accessed May 20, 2015, http://www2.archivists.org/glossary/terms/o/original-order.
} 
Not all archivists agree with the idea of creating an artificial order. U of I archivist William J. Maher stated that "archivists do not rearrange the material they receive to create the illusion of greater accessibility or rationality in the records because doing so would violate the integrity and meaning of the records." ${ }^{, 14}$ While archival theory can and does evolve - Maher's book was published in 1992 - in Understanding Archives and Manuscripts, published in 2006, James M. O'Toole and Richard J. Cox stated, "the archivist accepts the order and arrangement the records already have, rather than trying to make one up after the fact." ${ }^{\prime 15}$ This is in direct conflict with the SAA's views. Neither is necessarily incorrect; it is up to the individual archivist to choose which way a collection is processed. If a collection is a high-use or high-profile collection, an archivist may choose to spend the time putting order to a folder of unorganized records; if it is not, the record folder may stay in the same arrangement as it was received. Regardless of whether the archivist chooses to organize records within a folder or not, these records are never to be mixed with records from another creator, or in with another folder within those records. The only exception to that would be if the record was obviously misfiled, such as if a press release from President Bowman regarding presidential scholar award recipients was filed in with athletic director candidate records.

From the outside, processing archival records takes little more effort than receiving a box of records, looking over the records in case records have been misfiled, then putting the box on a shelf. In reality, the next step in arranging records, the arrangement and description of the records, is where archival theory varies as widely as

\footnotetext{
${ }^{14}$ William J. Maher, The Management of College and University Archives (Lanham, MD: Scarecrow Press, Inc., 1992), 76.

${ }^{15}$ James M. O’Toole and Richard J. Cox, Understanding Archives and Manuscripts (Chicago: Society of American Archivists, 2006), 104.
} 
archivists themselves. The first step is accessioning the records. Usually, an accession record is created, which notes the records' date, title, the extent, condition, transferring office or donor, any conservation needs, and any access restrictions. Some archives will make that information available in their online database, if one exists, to inform users that the collection exists in an unprocessed form at the archives.

Accessioning is standard practice, laying "the basis for most of the subsequent handling of records and manuscripts." 16 An archives will have some sort of accession record, even if it exists only as a paper record. Funding, staffing, backlog and the importance of the record group play a role in whether the record group is made available in an online database. For example, EIU has a very limited online database due to funding, staffing, and backlog. Much of the archival collection is not available to be searched in its online database, and they make that known with a note on their webpage stating that "inventory lists are available at the Archives," indicating that there are more collections available, but the list is in hardcopy only. ${ }^{17}$ There is no list of accessioned records available online. U of I, SIU, and ISU have at least some of their accessioned records online as unprocessed material. The amount of accessioned unprocessed records for these institutions depends more on staffing, backlog, and the importance of the record group than on funding.

The next step is arrangement and description. There are numerous methods of arranging and describing record groups. Archivists usually use a combination of methods to arrange and describe their holding, sometimes within one record group. The idea is to get collections processed as efficiently and thoroughly as possible to both preserve the

\footnotetext{
${ }^{16}$ Maher, The Management of College and University Archives," 69.

${ }^{17}$ Booth Library, University Archives, Eastern Illinois University, accessed May 21, 2015, http://www.library.eiu.edu/archives/.
} 
collections and to make them available for use.

The National Archives and Records Administration (NARA) lays out the traditional method of processing collections. When processing a collection, NARA recommends removing metal fasteners, unless those fasteners are stainless steel due to the damage that could be caused to the documents from these objects rusting. ${ }^{18}$ They also recommend transferring records to acid-free folders if there is any question as to the type of folder already housing the records. ${ }^{19}$ O'Toole and Cox stated that folded documents should be flattened out, and rusting staples and paper clips be removed. ${ }^{20}$ But going through a collection, whether small or large, and removing those items is a timeconsuming task. The archivist must go item by item to ensure there are no items that could be damaging to the records and that all folded records have been flattened. This is basically arrangement at the folder level, something that archival authors since the mid1960s have dismissed as "having little utility and being thoroughly impractical for modern collections." ${ }^{21}$ Yet, how else is an archivist to accomplish those tasks?

At both the ISU and SIU archives, Anderson and Gorzalski follow the traditional method of processing, and rarely have collections described at the item level. The only time that type of processing would occur would be if the collection was high-profile collection. Most of the collections are described at the folder level, although some collections, such as the June Rose Colby papers in the ISU archives, appear to be processed at the item level while in actuality they are processed at the folder level. This

\footnotetext{
${ }^{18}$ National Archives and Records Administration, Preservation of Archival Records: Holdings Maintenance at the National Archives, Mary Lynn Ritzenthaler, Technical Information Paper Number 6 (1990), accessed May4, 2015, http://www.archives.gov/preservation/holdings-maintenance/.

${ }^{19}$ Ibid.

${ }^{20}$ O'Toole and Cox, 104.

${ }^{21}$ Mark A. Greene and Dennis Meissner, "More Product, Less Process: Revamping Traditional Archival Processing," American Archivist 68, no. 2 (September 2005): 213.
} 
is because each manuscript in the collection has its own folder.

Weeding is another time-consuming, labor-intensive task. Weeding is the removal of materials that have no archival value. Some weeding is done during appraisal when the archivist first inspects the materials. There may be records that the archivist is unable to take, such as employee evaluations. These records would be removed before the archivist takes possession of the records. Maher suggests that any weeding done during processing should be done at the folder level. ${ }^{22}$ Yet Maher seems to contradict himself when discussing preservation. One of the steps he includes along with removing fasteners, and refoldering in acid-free folders is "weeding of duplicate and nonarchival documents. ${ }^{23}$ It is difficult to weed out duplicate and nonarchival documents if processing is not done at the item level. The amount of weeding done again depends on the collection and on the archivist. However, if an office follows the retention schedule provided by the records management program, much of the weeding would be complete before the archivist receives the records. That, of course, would not be the case for donated records, say a professor's papers. The archivist would then have the task of sorting through those papers and removing duplicates and non-historical papers, like a phone message that stated, "Call Bill."

Description is "the creation of an accurate representation of the archival material by the process of capturing, collating, analyzing, and organizing information that serves to identify archival material and to explain the context and records systems that produced it, as well as the results of these processes. ${ }^{, 24}$ One of the principles of description is that

\footnotetext{
${ }^{22}$ Maher, The Management of College and University Archives," 49.

${ }^{23}$ Ibid., 115-116.

${ }^{24}$ Society of American Archivists, Describing Archives: A Content Standard, (Chicago: Society of American Archivists, 2013), xvi.
} 
the level of description corresponds to the level of arrangement. So, if an archivist chooses to describe a collection to the item level, the collection should be arranged at the item level. Accordingly, if a collection is described at the box level, the collection should have been arranged at the box level. However, as has been shown previously, collections are many times arranged at the item level through weeding and preservation, but these collections are still described at the folder level.

Unless sufficiently staffed to handle such laborious processes, it is inevitable that an archive will have a backlog of collections to process. In archives such as U of I, EIU, and SIU where records come into the archives on a regular basis, incoming records and collections will far outnumber the number of records and collections being processed, leading to an ever-growing backlog. In a 2003-2004 survey of repositories, Mark A. Greene and Dennis Meissner found that 34 percent of repositories stated that over half of their holdings were not processed, and another 60 percent stated nearly a third of their holding were unprocessed. ${ }^{25}$ Another outcome from the survey was that 90 percent of the repositories weed duplicates, which brings processing down to the item level, ${ }^{26}$ and 85 percent refolder records in acid-free folders. ${ }^{27}$ The Greene/Meissner survey also found that 82 percent of repositories "sometimes, usually, or always create finding aids with collection- and series-level descriptions; 76 percent create finding aids with a biography or administrative history; and 74 percent create container lists with folder-level content description.",28

Greene and Meissner connected backlog to the traditional processing method and

\footnotetext{
${ }^{25}$ Greene and Meissner, 210.

${ }^{26}$ Ibid., 215.

${ }^{27}$ Ibid., 230.

${ }^{28}$ Ibid., 230.
} 
proposed a more efficient processing method than the traditional method of processing.

They believed that those labor-intensive, time-consuming processes hampered archivists from efficiently processing collections and making them available to users. Their guidelines "[expedite] getting collection materials in the hands of users, [assure] arrangement of materials adequate to user needs, [take] the minimal steps necessary to physically preserve collection materials, [and describe] materials sufficient to promote use. ${ }^{29}$ Rather than taking the large amount of time to remove fasteners, the authors advise leaving them and housing the records in a repository with proper climate control, where "with good climate control, metal fasteners should not rust." ${ }^{30}$ As for refoldering collections in acid-free folders, something NARA holds as an essential component of preserving records, ${ }^{31}$ Greene and Meissner note that "no studies have been done on the effect that standard manila folders have on collection material when stored in proper environmental conditions," nor have any studies been conducted on the effect of buffered folders when stored in the proper environmental conditions. ${ }^{32}$ Thus, do archivists spend time on a process that may or may not significantly affect records?

In working with collections in the ISU archives, I have seen some collections, such as a container from the Berlo collection, where the staples were not removed. While I was processing the records of the Student Government Association as a project in the Archives and Manuscripts class, Anderson instructed me to remove all paper clips and staples and replace them, if necessary, with plastic paper clips. Why the difference in processes? It depends on the archivist and the condition of the fasteners. Some archivists

\footnotetext{
${ }^{29}$ Ibid., 212.

${ }^{30}$ Ibid., 231.

${ }^{31}$ National Archives and Records Administration, Preservation of Archival Records: Holdings Maintenance at the National Archives.

${ }^{32}$ Greene and Meissner, 231.
} 
insist that all potentially damaging fasteners be removed. Others, like Anderson, have the fasteners removed if they are already rusted or pose an imminent threat to the records. The Student Government collection was fairly small, only two linear feet, but had fasteners that were rusting, hence the need to remove them. With having to remove fasteners, weed the records, and create order out of chaos, it took me a minimum of two months working five hours per week, along with the two or three days when I was able to spend seven hours processing. So, I estimate that it took me a minimum of 54 hours to process a collection of 2 linear feet.

U of I follows the practice Greene and Meissner laid out, More Product, Less Process (MPLP), although according to Maher, the university was processing collections using minimal processing under archivist Maynard Brichford in the 1960s. As a result, their backlog is small for the size and number of records and collections they receive. In a review of their database, descriptions and finding aids for some of the collections were by item, such as the Folke Dovring Papers. A few were topical, like the Robert D. Carmichael papers, with box numbers following the topic indicating which box or boxes contained the information. Still others, like the Robert Gehlmann Bone collection at U of I, are described at the box level.

What implications did the survey find regarding description? Since the goal is to "maximize the accessibility of collection materials to users," Greene and Meissner believe that "arrangement, preservation, and description should all work in harmony." "33 This means that if an archivist intends to describe a collection at the series level then the collection should not have any arrangement or preservation done at any other level. For example, archivist Anna Adams received six linear feet of records from the Dean's Office

${ }^{33}$ Ibid, 240. 
of the College of Arts and Sciences. The records can be organized into three categories awards, finances, and programs. Each of those categories would be a series. Adams wants to make this collection available as soon as possible, so she decides to describe this to the series level. The only arrangement, preservation, or description done would be on that same level. However, Adams decides that the awards series should be processed to the folder level so users would be aware of the various awards like Outstanding College Researcher and Outstanding College Teacher. Adams is certainly able to do that, and she would arrange, preserve, and describe the awards series down to the folder level.

One drawback to using minimal processing would come in the descriptive aspect. With only a general description of the collection, researchers would know that the collection is available but would not know if the collection contained the information needed. Hopefully, the researcher would make an inquiry regarding the collection and reference staff would then have to sort through the collection to obtain an answer about contents. That process would take a bit more time for the researcher and for reference staff, but if the collection had not been made available, the researcher would not have known it was out there. But just because a collection has been minimally processed does not mean that it has to remain that way. Should backlog decrease significantly, or if there is substantial interest in the collection, it can then be processed more thoroughly.

In Anderson's process, description and the creation of a finding aid are tied together. A finding aid is "a single document that places the materials in context by consolidating information about the collection, such as acquisition and processing; provenance, including administrative history or biographical note; scope of the collection, including size, subjects, media; organization and arrangement; and an inventory of the 
series and the folders." ${ }^{34}$ The finding aid is written in EAD (Encoded Archival Description) and once completed, is added to the webpage. It then becomes searchable. Anderson's backlog comes mainly from the fact the most of the collections had not been processed or were processed incorrectly. She also had to start from scratch when creating her finding aids and putting them online.

SIU also uses EAD, much like ISU. Gorzalski describes collections usually to the folder level, but if photographs are part of the collection, such as the College of Agricultural Sciences collection, the collection is also described at the item level. Most of the other collections, such as the Graduate Council collection, are described to the folder level. Gorzalski attributes his backlog to lack of staffing rather than to the method of processing.

U of I's archives, all three of them, write finding aids using EAD. However, if there is more detailed description at the folder level for older collections, there is a downloadable PDF containing that description. Having had an archivist from the outset, the collections were processed correctly, and all that had to be done was write the EAD finding aid and attach the already existing finding aid in the form of a PDF.

The few collections available on EIU's website are described to the item level, like the Office of the President, 1899 -1933 collection. Others, such as the Eastern Illinois University Centennial collection, are described at the collection level - the description for this collection states that it is a collection of administrative records. ${ }^{35}$ Still others are described to the series level. Most of the collections I reviewed were described

\footnotetext{
34 “Glossary," Society of American Archivists, accessed May 20, 2015, http://www2.archivists.org/glossary/terms/f/finding-aid

${ }^{35}$ Eastern Illinois University Centennial collection, Eastern Illinois University Archives, Charleston, IL, accessed May 20, 2015. http://booth.library.eiu.edu/archon/index.php?p=collections /controlcard\&id=111\&q=centennial.
} 
very minimally, leading me to believe that they were also processed minimally. That would make sense considering the severe straights the archives is in with less than an adequate staffing and funding.

Several studies have attempted to quantify the cost of processing collections. A 1978-1979 study conducted by W. N. Davis, Jr. found that it took staff, which consisted of archivists and clerical staff, eight hours per cubic foot to process a collection. ${ }^{36} \mathrm{~A}$ 1980 study conducted by Maher concluded that it took staff 3.0 hours per cubic foot to process office records and 6.9 hours per cubic foot to process personal papers. ${ }^{37}$ If an average of those three times (approximately 6 hours) was used to calculate the time to process a collection of 44 linear feet (assuming the containers were one foot by one foot by one foot), it would take about 264 hours to process that collection, or 35 work days at 7.5 hours each day. It is not difficult to see why archives have such a backlog. Greene and Meissner suggest that their MPLP approach could bring processing time down to an average of four hours per cubic foot. ${ }^{38}$ Using the example of processing a collection of 44 linear feet, the time to process that collection at a minimal level would be approximately 176 hours, or about 23 days at 7.5 hours per day.

Another area where I found discrepancies between the four archives was their archival databases. Each university archive can be searched by entering a term, or by browsing the collections alphabetically by collection, digital content, subject, creator,or record group. It should be fairly straightforward: if a researcher wanted to find out about ISU President Bone, he or she could enter "Bone," or browse under the "Bs" to find the

\footnotetext{
${ }^{36}$ W. N. Davis, Jr., "Budgeting for Archival Processing," The American Archivist 43, no. 2 (Spring 1980): 211.

${ }^{37}$ William J. Maher, Measurement and Analysis of Processing Costs in Academic Archives," College and Research Libraries 43, no. 1 (January 1982): 62.

${ }^{38}$ Greene and Meissner, 253.
} 
collection. U of I's database is a little less intuitive, but still simple. It has tabs for campus unit, name, subject, series title, and image/E-record title. As I was looking for the collection from the Graduate School of Library and Information Science, I looked under "L" for library under the "Name" tab. I found nothing. I then realized that "Name" would lead me to names of people or organizations. I then looked under "L" in the subject tab and found the collection. SIU and EIU, while having the same tabs as ISU, does not have the ease of use. For example, as I browsed in SIU's database, the Sidney Fox papers were under "S" rather than "F." That would be fine if the collection were also under "F," but it is not. The same holds for EIU. The Burl Ives collections was under " $\mathrm{B}$ " for Burl. It is a small issue, but when dealing with an archive, there is an expectation that rules of alphabetizing are adhered to.

As far as outreach goes, U of I, ISU and SIU utilize social media and blogs. ISU and SIU both have Facebook pages, as does SLC archives at U of I. All three use Twitter and have blogs. The only outreach EIU does is through The Keep. EIU's traditional archives has no social media presence. At U of I, SIU, and EIU, since the records management programs overlap with the archives in funneling records to the archives, the archivists do not have to do much outreach on campus. Maher and Swain at U of I, and Gorzalski at SIU are able to focus their attention on alumni, and when other records fall into the scope of the outside collections the archives house, on collecting records relating to local, regional, and state history. Anderson has to focus much of her outreach time on ISU faculty and staff, informing them of the existence of the archives and collecting records that should already be coming to her automatically through the records management program. She does have exhibits during Homecoming and other events 
with high-alumni traffic and in December spoke at an ISU alumni reception in Springfield, Illinois.

The archives at ISU shares many traits with the other three universities. ISU and SIU archives use the traditional method of processing and description, but vary the level of description when the collection warrants it. ISU, SIU, and U of I archives use social media to engage faculty, staff, and alumni. ISU and U of I archives were founded through a university presidential decree as the official repositories of university records for their respective universities. ISU and SIU hired full-time archivists at around the same time. All four university archives are housed in spaces that are not ideal for preserving archival records and make use of interns and graduate students. The one main difference between ISU's archives and the other university archives is that ISU's archives do not have an active records management program that directs university records to the archives. Given all these similarities, both SIU and ISU are fairly typical university archives, while U of I and EIU are atypical, with U of I at the high end of the scale and EIU at the lower end of the scale. 


\section{CHAPTER VI}

\section{CONCLUSION}

Is the archives at Illinois State University a model Illinois university archive in development, processes, collecting policies, and challenges? In three of the four categories - development, processes, and challenges - I believe that it is. In reviewing the histories of the four archives and comparing them to each other and to various surveys conducted on college and university archives, ISU fits well into the typical model of a university archives.

The ISU archives is very typical of university archives in that it began in the early 1970s, as did over 50 percent of public university archives. The archives is also housed under the umbrella of the university library and was headed by special collections librarians or history professors until a professional archivist was hired. This, too is typical of public universities, as in 1962, 91 percent of university archives were headed by librarians, and in 1979, 89 percent were housed in libraries and 82 percent reported to library administration. As discussed in chapter four, both its previous and current spaces were adapted for archival use, but those spaces do not meet the SAA standards for an archival repository. In 1979, even at its current location, the archive building would be typical in that 57 percent of archives could not have their temperature controlled separately from the rest of the building, and 70 percent could not adjust humidity levels. 
As for processing, the methods for processing collections are within the standards for processing archival collections, as per chapter four. Materials are rehoused in acidfree boxes and folders. Most collections are processed at the item level but described at the folder level, with finding aids available through an online database written in EAD. Like 60 percent of other university archives, there is a significant backlog of collections to be processed. The archivist also spends much of her time in outreach activities aimed at both university employees and alumni.

Challenges faced by the ISU archives are also typical for university archives. The challenges include funding, staffing, space, security, and environmental conditions. As discussed in chapter four, all of the universities examined struggled with these elements in one way or another. Even the archive at $\mathrm{U}$ of I, the largest and best funded university of the four examined, has funding, space, security, and environmental condition issues. The ability to obtain enough funding at a public university is not an easy task, as many factors affect the overall funding. State politics play an important role in deciding budget allocations for public universities. In Illinois, public universities face the specter of double-digit cuts in funding, with numbers as high as 31 percent being tossed around. For the archives to survive, it must have proven itself as a part of the overall mission of the university.

Where ISU falls short, through no fault of its own, is in collecting policies. Anderson does a tremendous job in her efforts to obtain college and departmental records, but can only go so far. She is hindered in her efforts by ISU's lack of a substantial records management program. Granted, Illinois state law does not mandate that a records management schedule be followed unless records are to be destroyed, but 
ISU is the only state university examined that does not have an active records management program, and is the only university to specifically tell its personnel on the records management site that they do not have to follow the retention schedule for the destruction or archiving of records, as long as the records that should be destroyed or archived are appropriately disposed of at some point in time.

How can these deficiencies be corrected? First, ISU's archives needs an oncampus presence. Whether it be a new building or an existing building adapted to house the archives, having the archives physically on the campus would increase its visibility and aid Anderson in her outreach efforts.

Second, university administration need to view the archives as the institutional repository for its non-current records, and not just a place to house university memorabilia. One way to accomplish this would be putting more emphasis on the records management program. Another way would be for the library to recognize the archives as a distinct entity from itself and set up a budget line for the archives that would be sufficient to hire a civil service worker for the office work, as well as another archivist to process collections and supervise graduate assistants, IRAD interns, and volunteers.

Of course, none of these this can come to fruition without adequate funding. Without funding, an archive cannot be staffed, capital improvements cannot be made, archival supplies cannot be ordered, nor can a records management unit be formed. The use of graduate students and interns eases some of the funding and staffing problems, but only temporarily. Students may stay at an archive for a semester, for two years, or anywhere in between. Then a new crop comes in and must be trained, taking precious time away from processing and outreach activities. As funds become tighter, one of the 
first things a department can cut is the graduate student workers. Grants are also a way to ease funding shortages, but they are usually for specific projects. Vying for evershrinking pool of grant money in a highly competitive field of equally deserving programs leaves no guarantees of funding for a project for any length of time.

The one thing that could infuse some monies into the archives would be transferring the records management program to the archives. This would allow the university to salvage its administrative history, as well as save itself from more state fines for a non-compliant records management program. While departments still could not be forced to archive or dispose of their records according to the retention schedule, Anderson could, with the help of designated department records managers - the office staff that is already in place in the offices - educate departments, help them with file arrangement, and encourage departments to follow the retention schedule by showing them the advantages of following the schedule, i.e. easier access to records, and fewer filing cabinets and storage needs. With relatively little funding, possibly the cost of an additional staff member, the archives could then be seen by university faculty, students, and staff as more than a place full of fun artifacts from the past, but as a repository of university administrative history, having both a practical value and a research value. 


\section{REFERENCES}

\section{Primary Sources}

Braden, Samuel Edward, Presidential Papers. Dr. JoAnn Rayfield Archives, Illinois State University, Normal, IL.

Centers for Disease Control and Prevention. "Mold.” Accessed June 8, 2015. http://www.cdc.gov/mold/faqs.htm\#affect.

Eastern Illinois University Centennial collection. University Archives, Charleston, IL. Accessed May 20, 2015. http://booth.library.eiu.edu/archon /index.php? $\mathrm{p}=$ collections/controlcard\&id=111\&q=centennial

Eastern Illinois University Records and Information Management. "What is Records and Information Management?” Accessed May 1, 2015. http://www.eiu.edu /recordsmanagement/what.php.

Illinois Secretary of State, Illinois Archives, Records Management Division. "Records Management Reference Manual for Illinois State Government Agencies.” 2014.

Illinois State University. "How to Use this Website to determine what to do with a Specific Record." Accessed May 4, 2015. http://recordsmanagement.illinoisstate.edu/.

Illinois State University. “Records Management.” Accessed May 4, 2015. http://recordsmanagement.illinoisstate.edu/.

Morris Library, Southern Illinois University. "University Archives Collection.” Accessed May 21, 2015. http://www.lib.siu.edu/university-archives.

National Archives and Records Administration. Preservation of Archival Records: Holdings Maintenance at the National Archives. Mary Lynn Ritzenthaler. Technical Information Paper Number 6 (1990). Accessed May 4, 2015. http://www.archives.gov/preservation/holdings-maintenance/.

National Archives and Records Administration. Records and Information Management Self-Evaluation Guide. Accessed May 4, 2015. http://www.archives.gov/records$\mathrm{mgmt} /$ publications/records-and-information-management-self-evaluationguide.pdf. 
Rayfield, JoAnn File. Dr. JoAnn Rayfield Archives, Illinois State University, Normal, IL.

Records and Information Management Services (RIMS) Task Force, University of Illinois, Champaign-Urbana. "Final Report." Accessed May 11, 2015. https://uofi.app.box.com/s/q96pqv6acgw0ri8fmz5y.

Sousa Archives and Center for American Music. "About.” Accessed April 27, 2015. http://archives.library.illinois.edu/sousa/about/.

Student Life and Culture Archives. "About.” Accessed April 27, 2015.

http://archives.library.illinois.edu/slc/about-2/.

Southern Illinois University Records Management. "Administration and Consulting." Accessed April 30, 2015. http://recordsmgmt.siu.edu/administration-andconsulting/index.html.

__. "Welcome to Records Management." Accessed May 5, 2015. http://recordsmgmt.siu.edu/.

State Records Act. Illinois Compiled Statutes, ch. 5, no. 160, sec. 1-26 (2003). Accessed May 4, 2015. http://www.ilga.gov/legislation/ilcs/ilcs3.asp?ActID=86 $\&$ ChapterID $=2$.

University Archives, Booth Library, Eastern Illinois University. Accessed May 21, 2015. http://www.library.eiu.edu/archives/.

University of Illinois. “About RIMS.” Accessed May 11, 2015. https://www.uillinois.edu/cio/services/rims/about_rims/.

—_. "Records and Information Management Services." Accessed May 11, 2015. https://www.uillinois.edu/cio/services/rims/.

_ . "University of Illinois Archives: Bringing History to Life." Accessed April 27, 2015. http://archives.library.illinois.edu/.

\section{Secondary Sources}

Brichford, Maynard. "The Illiarch.” In College and University Archives: Selected Readings, 1930. Chicago: Society of American Archivists, 1979.

Browne, Henry J. "An Appeal for Archives in Institutions of Higher Learning." The American Archivist 16, no. 3 (July 1953): 213-226.

Buck, Solon J. “Training of American Archivists.” The American Archivist 4, no. 2 (April 1941): 84-90.

Burckel Nicholas C. and Frank Cook. "A Profile of College and University Archives in the United States." American Archivist 45, no 4 (October 1982): 410-428. 
Champagne, Roger J. A Place for Education, Illinois State University, 1967-1977. Normal, IL: Illinois State University Foundation, 1978

Conway, Paul. "Perspectives on Archival Resources: The 1985 Census of Archival Institutions." American Archivist 50, no. 2 (Spring 1987): 174-191.

Crosby, Tim. "Director of Special Collections Named for Library." News (June 16, 2006). Accessed April 25, 2015. http://news.siu.edu/2006/06/061606tc6129.php.

Davis, Jr., W. N. "Budgeting for Archival Processing." The American Archivist 43, no. 2 (Spring 1980): 209-211.

"EIU's Electronic Repository, The Keep, Reaches Patrons Worldwide." Eastern Illinois University Media Relations, August 1, 2013. Accessed June 16, 2015. http://castle.eiu.edu/media/viewstory.php?action=880.

'Focus on Library Faculty: Leah Broaddus.' Cornerstone 3, no. 3 (Spring 2000): 1-11. Accessed April 25, 2015. http://opensiuc.lib.siu.edu/cgi/viewcontent.cgi?article $=1002 \&$ context $=$ morrisnews_cornerstone.

Freed, John. Educating Illinois: Illinois State University, 1857-2007. Virginia Beach, VA: Donning Co. Publishers, 2009.

Greene, Mark A. and Dennis Meissner. "More Product, Less Process: Revamping Traditional Archival Processing." American Archivist 68, no. 2 (September 2005): 208-263.

Hackbart-Dean, Pamela S., Leah Agne, \& Julie Mosbo. "History on the Move: Relocating Special Collections and Archives." (January 2010): 31-53. Accessed April 25, 2015. http://opensiuc.lib.siu.edu/morris_articles/57/.Jennings, John Melville. "Archival Activity in American Universities and Colleges." The American Archivist 12, no. 2 (April 1949): 155-163. Accessed March 1, 2015. http://americanarchivist.org/doi/pdf/10.17723/ aarc.12.2.j8217m30733353k6.

Jones, H. G. "Archival Training in American Universities, 1938-68." The American Archivist 31, no. 2 (April 1968): 135-154.

Kahn, Herman. "Some Comments on the Archival Vocation." The American Archivist 34, no. 1 (January 1971): 3-12.

Maher, William J. "The Illini Archives: A Laboratory for Retrospective Research." Illinois Libraries 63, no. 1 (March 1981): 269-274.

. "The Illini Archives in the 1980s." Illinois Libraries 69 no. 4 (October 1987): 584-587. 
- The Management of College and University Archives. Lanham, MD: Scarecrow Press, Inc., 1992.

- Measurement and Analysis of Processing Costs in Academic Archives." College and Research Libraries 43, no. 1 (January 1982): 59-67.

Mason, Philip P. "College and University Archives: 1962." The American Archivist 26, no. 2 (April 1963): 161-165.

Meyer, Linda M. "Historian as Archivist: History, Archives, and Outreach at Colorado State University." Journal of Archival Organization 9, no. 3-4 (July-December 2011). 226-236..

Norton, Margaret Cross. "Services and Resources of an Archives." In Norton on Archives: The Writings of Margaret Cross Norton on Archival and Records Management, edited by Thornton W. Mitchell, 70-85. Carbondale: Southern Illinois University Press, 1975.

Optical Storage Technology Association. "Technology Q \& A.” Accessed April 27, 2015 http://www.osta.org/technology/cdqa8.htm.

O’Toole James M. and Richard J. Cox. Understanding Archives and Manuscripts. Chicago: Society of American Archivists, 2006.

Pruitt, Gordon. "David Koch Retires at July's End." Cornerstone 1, no. 1 (Fall 2005): 17. Accessed April 25, 2015. http://opensiuc.lib.siu.edu/cgi /viewcontent.cgi?article=1012\&context=morrisnews_cornerstone.

—_. "Matt Gorzalski Named University Archivist." Cornerstone 7, no. 4 (Summer 2012): 1-7. Accessed April 25, 2015. http://opensiuc.lib.siu.edu /morrisnews_cornerstone/27/.

Russell, Mattie U. "The Influence of Historians on the Archival Profession in the United States." The American Archivist 46, no. 3, (July 1983): 277-285.

Schellenberg, T. R. Modern Archives: Principles and Techniques. Chicago: The Society of American Archivists, 1956.

Shipton, Clifford K. "The Harvard University Archives: Goal and Functions." Harvard Library Bulletin 1, no. 1 (Winter 1947): 101-108. Accessed March 5, 2015. http://pds.lib.harvard.edu/pds/view/2573358.

Society of American Archivists. Archival and Special Collections Facilities: Guidelines for Archivists, Librarians, Architects, and Engineers. Accessed May 21, 2015. http://www2.archivists.org/category/standards-type/guidelines. 
Describing Archives: A Content Standard. Chicago: Society of American Archivists, 2013. Accessed May 15, 2015.

http://files.archivists.org/pubs/DACS2E-2013.pdf/.

__. "Glossary.” Accessed May 20, 2015. http://www2.archivists.org/glossary.

—_ "Guidelines for College and University Archives.” Accessed May 21, 2015. http://www2.archivists.org/node/14801.

—_ "Guidelines for a Graduate Program in Archival Studies." Accessed March 2, 2015. http://www2.archivists.org/gpas.

Society of American Archivists Committee on College and University Archives. College and University Archives in the U.S. and Canada. Ann Arbor, MI: University of Michigan, 1972. Accessed June 14, 2015. http://babel.hathitrust.org/cgi/pt?id=mdp.39015071441235; view=1up;seq=1 .

Trinkaus-Randall, Gregor, James Reilly and Patricia Ford. "The Massachusetts Experiment: The Role of the Environment in Collection Preservation." The American Archivist. 77, no. 1 (Spring/Summer 2014): 133-150. Accessed June 8, 2015. http://americanarchivist.org.libproxy.lib.ilstu.edu/doi/pdf/10.17723 /aarc.77.1.kk006ng47132715j.

Van Schreeven, William. "Information Please: Finding Aids in State and Local Archival Depositories." The American Archivist 5, no. 3 (July 1942): 169-178.

Warner, Robert M. "Archival Training in the United States and Canada." The American Archivist 35, no. 3-4 (July 1972): 347-35.

—. "The Status of College and University Archives." The American Archivist 31, no. 3 (July 1968): 235-23.

Wilson, Dwight H. "Archives in Colleges and Universities: Some Comments on Data Collected by the Society's Committee on College and University Archives." The American Archivist 13, no. 4 (October 1950): 343-350. 